\author{
Anna Szczęsny \\ Uniwersytet Warszawski \\ a.m.szczesny@uw.edu.pl \\ ORCID: 0000-0001-8207-9338
}

\title{
NAZWY WŁASNE \\ W PRZESTRZENI MIEJSKIEJ JAKO \\ PROBLEM PRZEKŁADOWY. \\ SPOJRZENIE TŁUMACZA PRAKTYKA \\ I DYDAKTYKA TKUMACZENIA
}

DOI: http://dx.doi.org/10.12775/RP.2021.014

\begin{abstract}
Zarys treści: Artykuł jest poświęcony nazwom własnym oznaczającym obiekty w przestrzeni miejskiej, różnie klasyfikowanym z punktu widzenia onomastyki (chrematonomastyki w szczególności), a także onomastyki przekładowej. Omawiając wybrane koncepcje translatoryczne, autorka podkreśla funkcje tekstowe tych nazw oraz sposoby oddawania ich w tekście przekładu (techniki tłumaczeniowe). Ponadto zwraca uwagę na stosunkowo nowe zjawiska w tym obszarze działań translatorskich i paratranslatorskich, na możliwe i postulowane zmiany zakresu stosowanych zabiegów, m.in. transliteracji angielskiej, przede wszystkim w odniesieniu do sfery mediów i przestrzeni publicznej. Ostatnia część tekstu jest opisem propozycji dydaktycznych z przykładami z języka rosyjskiego i polskiego.
\end{abstract}

Słowa kluczowe: nazwy własne (onimy), chrematonimy, mikrotoponimy, urbanonimy, funkcje tekstowe, onomastyka przekładowa, działania paratranslatorskie, techniki tłumaczeniowe, transfer, tłumaczenie, rekomendacje dla tłumaczy

\section{Wstęp}

$\mathrm{N}$ azwy własne (onimy, propria) interesują zarówno onomastów, jak i tłumaczy praktyków, przekładoznawców oraz dydaktyków przekładu. Z powodu swej różnorodności i złożoności mogą one stanowić realną trudność 
przekładową, czasem wymagają nieszablonowych rozwiązań translatorskich. Podzielam stanowisko Artura Gałkowskiego, według którego onomastyka i przekładoznawstwo ${ }^{1}$ mają wspólny obszar badań i mogą czerpać wzajemnie ze swoich doświadczeń. Onomaści uwzględniają refleksje przekładoznawcze choćby dlatego, że dokonywane przez tłumaczy adaptacje obcych nazw własnych były historycznie jedną z podstawowych form ich funkcjonowania w nowym środowisku językowo-kulturowym (Gałkowski 2018b: 130). Poza tym niektórzy onomaści postulują, by uznać właściwości tekstu², funkcję onimu w tekście, jego wymiar pragmatyczny oraz wartość konotacyjną za istotne kryteria badania i opisu, obok tradycyjnych analiz nazwotwórczych (zob. np. Cieślikowa 2011:119,12133). Takie ukierunkowanie tekstowe badań niewątpliwie jest wspólne dla onomastów i translatoryków. Ci ostatni mogą a nawet powinni - sięgać do koncepcji onomastycznych: dzięki wiedzy na temat pochodzenia nazewnictwa, jego klasyfikacji oraz wzajemnych powiązań różnych klas onimów ${ }^{4}$, a także dzięki świadomości kształtowania się uzusu zyskują więcej możliwości efektywnego rozwiązywania problemów ekwiwalencji w odniesieniu do tych jednostek tekstu. Moje rozważania będą ukierunkowane przede wszystkim translatorycznie, czyli będą nastawione na to, co z osiągnięć onomastyki warto spożytkować w przekładzie i w dydaktyce przekładu.

W pierwszej części artykułu odwołam się do kilku ujęć i klasyfikacji onomastycznych uwzględniających nazewnictwo miejskie, które w moim przekonaniu mają istotny potencjał do wykorzystania w procesie tłumaczenia na jego różnych etapach.W części drugiej przywołam refleksje translatoryków w odniesieniu do interesującej mnie grupy onimów, skupiając się na sposobach ich oddawania w przekładzie. W części trzeciej opiszę krótko projekt zespołu językoznawców rosyjskich, którego celem było uporządkowanie

1 Autor (Gałkowski 2018b: 129) wyróżnia dwie subdziedziny: onomastykę translatoryczną (OT) i translatorykę onomastyczną (TO).

2 Chodzi o zróżnicowanie stylistyczno-gatunkowe: czy tekst reprezentuje odmianę pisaną, czy mówioną, czy ma charakter potoczny, obiegowy, czy raczej oficjalny, urzędowy itp.

3 A. Cieślikowa pisała o takich perspektywach badawczych w odniesieniu do chrematonimów, rozumianych w szerokim ujęciu jako nazwy wytworów człowieka, zarówno materialnych, jak i duchowych - a więc świadomie kreowanych (Cieślikowa 2011: 116).

4 Szczególnie interesujące jest tu zjawisko transonimizacji, czyli tworzenia nazw własnych od innych nazw własnych. Transonimizacja w szerokim zakresie obejmuje procesy nazwotwórcze zarówno bez wykładników formalnych (czyste przeniesienie danej nazwy do innej klasy), jak i z wykładnikami formalnymi (słowotwórczymi) - zob. Bijak 2017: 3. 
zasad oddawania nazw obiektów miejskich w języku angielskim na przykładzie Jekaterynburga. Projekt ten wydaje mi się interesujący ze względu na możliwe zastosowania w praktyce przekładu i w dydaktyce. W ostatniej części artykułu podam konkretne przykłady problemów tłumaczeniowych związanych $\mathrm{z}$ onomastykonem miejskim, analizowanych $\mathrm{w}$ ramach zajęć $\mathrm{z}$ przekładu pisemnego $\mathrm{z}$ języka rosyjskiego na polski. Zaproponuję także pewną sekwencję ćwiczeń wprowadzających do problematyki nazw własnych w tłumaczeniu.

\section{0 nazwach własnych w przestrzeni miejskiej z perspektywy onomastyki}

Nazwy własne występujące w przestrzeni miejskiej przyporządkowywane są przez onomastów do różnych grup. Najczęściej wskazuje się na ich związki $\mathrm{z}$ chrematonimami oraz $\mathrm{z}$ toponimami czy $\mathrm{z}$ antroponimami. W charakterystyce onimów miejskich oraz w opisie ich powiązań będę się posługiwać następującymi terminami ${ }^{5}$ : antroponim (nazwa osobowa oznaczająca osobę realną lub fikcyjną); chrematonim (w ujęciu maksymalistycznym: nazwa własna wytworu kulturowego, materialnego lub niematerialnego) i jego podtypy: ideonim (nazwa własna wytworu kultury artystycznej), socjoideonim (nazwa własna oznaczająca grupę, inicjatywę lub wydarzenie o charakterze społecznym lub kulturowym); makrotoponim (nazwa własna obiektu lub obszaru określonego geograficznie bądź administracyjnie, zamieszkanego lub nie, o szerokim zasięgu komunikacyjnym) i mikrotoponim (nazwa własna obiektu lub obszaru zwykle niezamieszkanego, o wąskim zasięgu komunikacyjnym); urbanonim (toponim miejski, nazwa własna obiektu w przestrzeni miejskiej) oraz jego podtypy, np. hodonim (nazwa własna drogi, zwykle miejskiej); ponadto egzonim (nazwa geograficzna w innym języku niż język obszaru, na którym występuje oznaczany przez nią obiekt).

Jeśli chodzi o chrematonimy, to ze względu na ich uwarunkowania tekstowe, kreatywność procesów nazwotwórczych, związki z innymi onimami oraz elementami obcojęzycznymi stanowią one specyficzny obiekt badawczy.

5 Skrócone definicje na podstawie opracowania Terminologia onomastyczna. Aktualizowana lista podstawowych haseł terminologii onomastycznej w języku polskim (Gałkowski 2012b). 
Aleksandra Cieślikowa (2011: 117-119), dostrzegając te czynniki, opowiadała się za nowym - interdyscyplinarnym i polimetodycznym podejściem do tej grupy nazw własnych:

Onomastyka przez chrematonimię zostaje uwikłana w rozmaite zależności, niekiedy odmienne od dawnych, wymuszając inne ujęcia, które pokazują zależności między nazwą a dyskursem, nazwą a różnymi rodzajami tekstu, nazwą a celem jej użycia (Cieślikowa 2011: 119).

W podobnym duchu wypowiada się Gałkowski, uznając chrematonimy za jednostki, które wymagają innowacyjnych narzędzi badawczych wykraczających poza granice dyscypliny, jaką jest onomastyka. Autor uznaje je za specyficzny fenomen, bardzo dynamiczny, właściwy wszystkim kulturom i językom:

Chrematonimy funkcjonujące w otoczeniu kulturowym nie są wyłącznie zwykłymi etykietami dla obiektów, którym pospiesznie nadaje się nazwy, aby je wyeksponować w szumie informacyjnym, zindywidualizować, zapamiętać, stosować w komunikacji. Kodują one stałą informację o nazywanej rzeczywistości, często w przemyślany sposób perswazyjny, mający wiele wspólnego z wytwarzaniem aktu mowy, a więc celem perlokucyjnym (Gałkowski 2011).

W tej samej pracy, postulującej autonomizację badań nad chrematonimami, autor uwzględnia ich aspekt translatoryczny, formułując spostrzeżenia na temat przetłumaczalności/nieprzetłumaczalności, tłumaczenia/ nietłumaczenia nazw własnych o przejrzystej motywacji, współistnienia wariantów wielojęzycznych (wprawdzie nie nazywa ich ekwiwalentami uznanymi, lecz o nie właśnie chodzi). Również w późniejszych pracach badacz podkreśla wielość perspektyw ${ }^{6}$ oraz naturalną interdyscyplinarność podejścia do chrematonimów (Gałkowski 2018a: 8-9).

Chrematonimy definiowane są bardzo szeroko, ze względu na swą wielofunkcyjność, lub też wąsko. Gałkowski zdecydowanie skłania się ku definicji maksymalistycznej chrematonimii, której zakres obejmuje nazwy obiektów i instytucji - w przeciwieństwie do definicji minimalistycznej,

6 To m.in. perspektywa funkcjonalna, nazwotwórcza, komunikacyjna, pragmatyczna, semantyczna, socjokulturowa, leksykograficzna. 
według której chrematonimy to wyłącznie nazwy wytworów kultury materialnej (Gałkowski 2018a: 2). Autor podtrzymuje zarazem przedstawioną w swoich wcześniejszych pracach propozycję klasyfikacji chrematonimów. Dzieli je na trzy podzbiory: chrematonimy marketingowe (związane ze sferą produkcji, zarówno nazwy produktów, jak i firm), społecznościowe (związane z działalnością człowieka w organizacjach, instytucjach, stowarzyszeniach) oraz ideacyjne (związane z działalnością artystyczną, naukową, edukacyjną, religijną). Podziały te nie są ostre: zakresy wyróżnionych klas mają części wspólne, nakładają się. Na przykład socjoideonimy - jak wskazuje sama nazwa - to pewna część wspólna chrematonimii ideacyjnej i społecznościowej (Gałkowski 2018a: 4). W każdym z trzech wymienionych wyżej podzbiorów chrematonimów Gałkowski (2018a: 6-8) wyróżnia dodatkowo terminy uogólniające (określające charakter ogólny i wymiar funkcjonalny) oraz uszczegóławiające (wynikające z natury obiektu noszącego konkretną nazwę $)^{7}$. Stanowią one dodatkowe kryteria podziałów wewnętrznych. Wiedza o przynależności danej nazwy do określonej grupy chrematonimów może być pomocna tłumaczowi w ustaleniu poziomu ekwiwalencji ${ }^{8}$ i w poszukiwaniach odpowiedników uznanych.

Obok chrematonimów, bardzo licznych we współczesnej przestrzeni miejskiej, występują w niej przede wszystkim nazwy reprezentujące toponimię. Trzeba przyznać, że ustalenie przynależności nazwy obiektu do jednej z tych dwu sfer ${ }^{9}$ nie jest proste ani jednoznaczne. Ponadto pociąga za sobą określone konsekwencje: np. na mocy Uchwały nr 7/2016 z dnia 19 października 2016 roku Komisja Standaryzacji Nazw Geograficznych usunęła z list budowli egzonim Galeria Tretiakowska, ponieważ bardziej istotny okazał się charakter chrematonimiczny tej nazwy (muzeonim, zarazem instytucjonim) niż jej charakter toponimiczny. Przekładoznawcy (m.in. Hejwowski 2004 ${ }^{10}$; Lewicki 2017; Kozłowska, Szczęsny 2018) posługują się

7 W mojej analizie przykładów uwzględnię kilka określeń chrematonimów zawartych we wzmiankowanej klasyfikacji. Będą to w sensie uogólniającym ergonimy (nazwy firm) i socjoideonimy, w sensie szczegółowym zaś - teatronimy i instytucjonimy.

8 Szczególnie dotyczy to chrematonimów wielokomponentowych, zawierających inne nazwy własne, np. antroponimy.

9 Przyporządkowanie klasyfikacyjne jest bardziej istotne dla onomastów niż dla tłumaczy i przekładoznawców.

10 Krzysztof Hejwowski w swojej późniejszej pracy (2015: 139) zrezygnował z podziału toponimów na makro- i mikrotoponimy. 
terminem mikrotoponim w innym (lub częściowo wspólnym) znaczeniu niż onomaści ${ }^{11}$, koncentrując się bądź na skali obszaru czy obiektu, bądź też na jego rozpoznawalności i powszechności w sferze komunikacji. Roman Lewicki (2017: 271) zastrzega, że klasyfikacja, którą przyjmuje - a jest w niej obecny również mikrotoponim - ma charakter roboczy ${ }^{12}$. Właściwie taka konstatacja znosi dyskusję wokół definicji mikrotoponimu. Mimo to warto, także w kontekście translatorycznym, operować terminologią skorelowaną $\mathrm{z}$ terminologią onomastyczną, a być może w ogóle zrezygnować $\mathrm{z}$ używania tego terminu.

Jakie jest miejsce urbanonimu w systemie terminologicznym onomastyki, jakie są jego relacje z toponimią (mikrotoponimią w ujęciu translatoryków) oraz chrematonimią? Termin ów zadomowił się na dobre w onomastyce słowiańskiej, natomiast jest praktycznie nieobecny w pracach zachodnich, nie ma go również na liście $\operatorname{ICOS}^{13}$. Problemy związane z urbanonimem na gruncie onomastyki rosyjskiej - w odniesieniu do międzynarodowej omawiają szczegółowo Roman Razumow i Siergiej Goriajew (Razumov, Goryayev 2019) Autorzy kreślą historię pojawienia się tego terminu w obiegu naukowym, począwszy od terminu mikrotoponim w latach 60. i 70., do ostatecznego utrwalenia się w postaci urbanonim od początku pierwszego dziesięciolecia XXI wieku. Omawiają także jego ewolucję w rosyjskich pracach onomastycznych oraz w słownikach terminologicznych, zwracając przy tym uwagę na rozdrobnienie terminów mu podporządkowanych ${ }^{14}$.

11 Bardzo sugestywną ilustracją tego stanu rzeczy może być przegląd definicji mikrotoponimu w pracy Wojciecha Włoskowicza (Włoskowicz 2021: 125-129), w której autor opowiada się za skalarnym, a nie binarnym rozumieniem terminów makrotoponim i mikrotoponim. Autor w swojej rozprawie na temat uzusu toponimicznego przyjmuje „[...] spektralną koncepcję mikrotoponimu i makrotoponimu jako biegunów skali wyznaczanej przez wielkość wspólnot komunikatywnych” (Włoskowicz 2021: 129). We wspomnianej pracy znajduje się bardzo szeroki przegląd historyczny definicji toponimu w ogóle, odzwierciedlający zmiany paradygmatów badawczych i kryteriów klasyfikacyjnych, przede wszystkim z uwzględnieniem nurtu semantycznego oraz socjologicznego.

12 W roboczej klasyfikacji (Lewicki 2017: 271) znajdują się m.in. mikrotoponimy rozumiane jako nazwy dzielnic, osiedli, ulic, placów, parków, skwerów, mostów, budowli. Chrematonimy ujmuje autor w zakresie bliskim chrematonimom marketingowym i częściowo ideacyjnym oraz społecznościowym w rozumieniu Gałkowskiego.

13 Termin został uwzględniony na Aktualizowanej liście podstawowych haseł terminologii onomastycznej w języku polskim (Gałkowski 2012b): „Urbanonim - nazwa własna obiektu występującego w przestrzeni miejskiej, np. ulicy, placu, parku, budynku, instytucji”. Nie figuruje on natomiast na Liście ICOS kluczowych terminów onomastycznych 2018.

14 Autorzy przywołują opinię Wasilija Supruna (Suprun 2011: 36 - za Razumov, Go- 
Autorzy podkreślają, że do podstawowego znaczenia ('rodzaj toponimu, nazwa własna dowolnego obiektu topograficznego znajdującego się w mieście') dołączyły takie jak 'nazwa własna dowolnego obiektu miejskiego, w tym komercyjnego' (jak sklep, restauracja, kawiarnia itp. - Razumov, Goryayev 2019: 135-136, 140). To wyraz tendencji, według której do urbanonimów zaliczane są wszelkie typy nazw własnych obecnych w przestrzeni miejskiej. W efekcie trudno je uznawać nadal za podklasę toponimów ${ }^{15}$. Autorzy postulują zarówno wprowadzenie terminu urbanonim do listy podstawowych terminów ICOS, jak i usystematyzowanie terminów niższego rzędu, dla których stanowiłby on hiperonim. $W$ pełni podzielam stanowisko badaczy, ponieważ również w piśmiennictwie polskim termin urbanonim jest powszechnie stosowany.

Na zakończenie tej części artykułu przedstawię jeszcze wybrane koncepcje opisu i badania nazw własnych, które w odniesieniu do onomastykonu miejskiego mogą być pomocne w procesie przekładu.

Podziały onimów opierają się na różnych kryteriach, przede wszystkim: semantycznym, strukturalnym oraz kulturowym. Historię tych trzech głównych ujęć na przykładzie nazw ulic omawia pokrótce Krystyna Data (Data 2015: 81-82). Początkowo, w latach 60. XX wieku, onomaści interesowali się w największym stopniu właściwościami językowymi (strukturalnymi) nazw ulic. Ten nurt badań jest aktualny do dziś. Późniejsze chronologicznie jest kryterium semantyczne klasyfikacji, wciąż chętnie stosowane, choć nie zawsze pozwala ono na pewne przypisanie danej nazwy do konkretnej grupy, jeśli jej motywacja nie jest jednoznaczna. Trzeci nurt w badaniach kulturowy - przypada na początek XXI wieku, a jego niezaprzeczalną wartością jest pomoc w ustaleniu motywacji nazwy, uwzględnienie $\mathrm{w}$ analizie ważnych dla lokalnej społeczności wydarzeń, zjawisk oraz postaci, które znalazły swe odbicie w nazewnictwie lub przyczyniły się do jego zmian. Szczególnie to ostatnie podejście współbrzmi z refleksjami translatoryków na temat kontekstowego badania onimów oraz ich funkcjonowania w kulturze

ryayev 2019: 132) na temat mnożenia terminów obejmujących już nawet nie jakąś klasę onimów, lecz wręcz niewielkie grupy nazw własnych (lub wyrazów do nich podobnych), przez co onomastyka operuje coraz mniej zrozumiałym, hermetycznym językiem.

15 W tym znaczeniu nazwy takich obiektów stanowią odmiany chrematonimów - marketingowych, ideacyjnych, społecznościowych (według klasyfikacji Gałkowskiego), czasem mają podwójne „przyporządkowanie”, o czym była mowa wyżej. 
wyjściowej (i poniekąd docelowej), z uwzględnieniem sfery konotacyjnej (Lewicki 2017).

Wymienione wyżej sposoby opisu onomastykonu mogą być łączone (i zwykle są łączone) ze sobą, choć Cieślikowa (2011: 119) sygnalizowała pewien dylemat dotyczący tego, w jakim stopniu należy uwzględniać „encyklopedię", czyli wiedzę o desygnacie, a w jakim wiedzę o języku.

Na przykład Bogusław Dunaj i Mirosława Mycawka ${ }^{16}$ (2012: 173-174) łączą podejście strukturalne z semantycznym, za punkt wyjścia przyjmując to pierwsze, i wyodrębniają trzy grupy nazw: nazwy przeniesione, nazwy derywowane oraz konstrukcje składniowe ${ }^{17}$. Autorzy podkreślają, że cel badań oraz specyfika materiału w największym stopniu determinują hierarchię kryteriów klasyfikacyjnych. W odniesieniu do chrematonimów, grupy najbardziej zróżnicowanej, ich zdaniem najlepiej się sprawdza kryterium formalne. Nazwy obcojęzyczne zaś, coraz bardziej widoczne we współczesnym onomastykonie ${ }^{18}$, należałoby przypisać do konkretnych grup strukturalnych (Dunaj, Mycawka 2012: 174). Prymat kryterium strukturalnego wydaje mi się wart uwagi w kontekście przekładu i analiz przekładoznawczych, zwłaszcza w parze języków blisko spokrewnionych, jak polski i rosyjski.

Z kolei Tatjana Szmielowa (Shmelëva 2019: 52-53), nie dystansując się całkowicie od kwestii formalnych (ujmuje je w kategoriach kodów substancjonalnych ${ }^{19}$ ), analizuje materiał onomastyczny przede wszystkim od strony oznaczanej, semantycznej. Autorka w opisie onomastykonu miejskiego koncentruje się na wartości komunikacyjnej planu treści i proponuje zastosowa-

16 Autorzy we wspomnianej pracy prezentują skrótowy przegląd różnych klasyfikacji na gruncie onomastyki polskiej. Bardzo rozbudowane studium toponimu, jego koncepcji, zakresu i definicji przedstawił Włoskowicz (2021: 27-152).

17 Ta ostatnia grupa wydaje się szczególnie interesująca w przypadku nazw nowych obiektów (chrematonimów w szerokim ujęciu) oraz nazw nieoficjalnych, bardzo istotnych w kontekście przekładu.

18 Sądzę, że może chodzić o słowa obce jako całe nazwy lub jako elementy nazw hybrydowych.

19 Substancjonalny, czyli dotyczący strony oznaczającej. Autorka wyróżnia dwie aktualne tendencje nazewnicze: stosowanie retrokodu (odwołującego się do ortografii lub leksyki historycznej) i ksenokodu (czerpiącego z zasobów obcojęzycznych - graficznych i leksykalnych). Ten ostatni jest zdecydowanie bardziej widoczny, często też dochodzi do łączenia elementów alfabetu łacińskiego z cyrylickim, tworzenia pseudoobcych słów poprzez specyficzny zapis słów rosyjskich itp. (Shmelëva 2019: 53-55). 
nie matrycy, którą tworzą kody i subkody pojęciowe ${ }^{20}$. Wypadkowa, „punkt przecięcia" tych kodów daje konkretne realizacje w postaci urbanonimu. Na przykład nazwę obiektu, w której skład wchodzi antroponim, możemy interpretować jako konfigurację kodu osobowego z subkodem posesywnym (jeśli obiekt ów należał kiedyś do osoby, której nazwisko jest częścią jego nazwy) lub też z subkodem memoratywnym (czyli pamiątkowym - jeśli nazwa obiektu ma uczcić osobę związaną z tym miejscem w przeszłości), a czasem z kodem ludycznym (jeśli nazwa obiektu miejskiego zawiera zabawny antroponim fikcyjny, który ma wywołać określone skojarzenia) ${ }^{21}$. Równocześnie w takim urbanonimie może być obecny subkod aksjologiczny, często związany $\mathrm{z}$ faktem upamiętnienia nazwiska osoby ważnej z punktu widzenia społeczności lokalnej. Jakie mogłoby być zastosowanie analizy tego typu w kontekście przekładu? Jeśli nawet nie oznaczałoby automatycznego wyboru techniki tłumaczeniowej - choć może wpłynąć na decyzję tłumacza np. o zastosowaniu przypisu - to z pewnością wnosi wiele od strony interpretacyjnej, ponieważ pozwala odczytać znacznie głębiej funkcje onimu w tekście wyjściowym, z całym bogactwem jego odwołań kulturowych i warstwy konotacyjnej.

Do wymiaru komunikacyjnego i społecznego onimów miejskich nawiązuje również Tatjana Nikitina (2019). Autorka bada, w jakim stopniu intencje kreatora nazwy trafiają do odbiorcy, czy są one uzasadnione i spełnione. Wiele uwagi poświęca nazwom nieoficjalnym (138-139), służącym mieszkańcom konkretnego miasta ${ }^{22}$. Takie ukierunkowanie badania zakłada interdyscyplinarność, przede wszystkim czerpanie z metodologii nauk społecznych, a także subdyscyplin $\mathrm{z}$ definicji interdyscyplinarnych, jak lingwokulturoznawstwo. Nazwy nieoficjalne to odrębny problem tłumaczeniowy, w którego rozwiązywaniu decydujące znaczenie ma kryterium pragmatyczne.

20 Autorka wyróżnia m.in. kod osobowy (персонныци), przestrzenny (пространственныци), przedmiotowy (предметныц̆), roślinny (растительный), zwierzęсу (анимальныц̆), aksjologiczny (аксиологический); w przypadku antroponimów istotne dla znaczenia są subkody: posesywny (посессивныцй), memoratywny, czyli pamiątkowy (меморативныц̆), ludyczny (игровой).

21 Chodzi o urbanonimy zawierające wymyślone personalia, kojarzące się z określoną sferą działalności: sklep, w którym sprzedawane są zasłony (ros. umopbl - trb. sztory), nosi nazwę Madame Sztorkina (Мадам Шторкина) - Shmelëva 2019: 60.

22 Podobnie jak Berit Sandnes (2016: 549-550), który podkreśla szczególną rolę miejscowych użytkowników języka w funkcjonowaniu onimów. 
Reasumując, implikacje translatoryczne badań onomastycznych nazewnictwa miejskiego wydają się zrozumiałe: wszak nowo powstające nazwy obiektów miejskich wymagają przyswojenia/adaptacji w przekładzie. Tłumacz i translatoryk może wynieść wiele korzyści z różnych opisów tej grupy onimów: od czysto formalnego, wzbogaconego o komponent semantyczny, do komunikacyjnego, uwzględniającego komponent kulturowy, ujmowanego interdyscyplinarnie. Wzięcie pod uwagę wymienionych tu aspektów może być pomocne na różnych etapach pracy: od pogłębionej analizy pretranslacyjnej do etapu tworzenia odpowiedników.

\section{Translatorycy wobec onimów}

Onimy w tłumaczeniu - poza kontekstem literackim, w wymiarze użytkowym - interesują przede wszystkim tych tłumaczy i badaczy, którzy pracują w parze języków o odmiennej grafii i/lub bardzo odległych typologicznie. Nieprzypadkowo więc tak wiele aktualnych publikacji na temat onimów w przekładzie dotyczy języków azjatyckich (chiński, japoński) oraz angielskiego, arabskiego i angielskiego, sporo jest też konfrontacji językowej rosyjsko-angielskiej. Czy w jakimś stopniu te doświadczenia można przenieść na grunt pary językowej rosyjski - polski (również polski - angielski)? Sądzę, że tak, odniosę się do tej kwestii w części 3 artykułu poświęconej omówieniu projektu kompromisowego podejścia do urbanonimów.

W refleksjach translatoryków wartość komunikacyjna onimu jest prymarna. Doceniając wagę nazw własnych jako obiektów badań przekładoznawczych, Lewicki postuluje, by poza klasycznymi ujęciami skoncentrowanymi na repertuarze technik tłumaczeniowych przypisanych onimom określonego typu analizować je w tekście docelowym: badać ich funkcje, osobliwości odbioru przez czytelnika docelowego (Lewicki 2017: 267-268, 278-280). Relacja ekwiwalencji również ma charakter międzytekstowy (nie międzyjęzykowy), a nawiązuje ją sam tłumacz jedynie w sytuacji braku odpowiedników uznanych, charakterystycznych dla konkretnej pary językowej (Lewicki 2017: 275). Takie ujęcie wyłącza właściwie ekwiwalenty uznane poza ramy technik tłumaczeniowych, do czego nawiążę jeszcze niżej.

Lewicki wyróżnia dwa podstawowe zadania realizowane przez onimy: to identyfikacja (skupienie na denotacji, jak np. imiona i nazwiska osób faktycznie żyjących) oraz sposób nazywania (uwzględniający stosunek 
emocjonalny do obiektu, jak np. zdrobnienia imion, lub skoncentrowany na funkcji charakteryzującej nazw znaczących, jak np. „nazwiska mówiące” postaci literackich, przy tym obejmujący całą sferę skojarzeniową $\left.{ }^{23}\right)$. W moich analizach posługuję się podobną dychotomią, a określenia funkcji onimów (konkretnie: toponimii) - lokalizująca i kulturowa (lub poznawcza) - zapożyczyłam od onomastyków ${ }^{24}$, ponieważ dobrze definiują oni role, jakie odgrywają onimy w tekście przekładu.

Lewicki klasyfikuje onimy przede wszystkim ze względu na ich funkcje tekstowe, natomiast $\mathrm{w}$ rozważaniach na temat technik tłumaczeniowych stosowanych w ich przypadku przyjmuje podział roboczy nazw własnych, odwołujący się do kryterium semantyczno-denotatywnego, w dużym stopniu zbieżny z klasyfikacjami onomastycznymi.

Nieco inaczej grupuje nazwy własne Gałkowski (2018b: 135-136). Wynika to, po pierwsze, z jego koncepcji translatoryki onomastycznej (TO) oraz onomastyki translatorycznej (OT), których obszary wzajemnie się przenikają, o czym wspominałam na wstępie. Autor określa stopień proprialności onimów w ujęciu skalarnym (wyróżniając 5 stopni, od maksymalnego do minimalnego), co ma bezpośredni wpływ na stopień przetłumaczalności, a dalej - na dobór techniki tłumaczeniowej, na sposób oddania go w tekście przekładu ${ }^{25}$. Po drugie, autor konsekwentnie za tłumaczenie (wyróżnienie A.S.) nazwy własnej uznaje:

23 Autor podkreśla, że ta funkcja może być niemożliwa do zachowania w przekładzie ze względu na różnice językowo-kulturowe - powiedziałabym, że jest najtrudniejsza, lecz nie niemożliwa: po prostu niekiedy niecelowa, ze względu na charakter projektu, a czasem osiągalna przy pomocy dodatkowych zabiegów, np. dodania przypisów. W jednym z tekstów analizowanych i tłumaczonych podczas moich zajęć studenci zdecydowali się na dodanie w przypisie eksplicytacji aluzji związanej z eklezjonimem (nazwą świątyni), zrozumiałej dla odbiorcy prymarnego, lecz nieczytelnej dla odbiorcy wtórnego (nawiązanie do pierwotnego, kontrowersyjnego wystroju głównego soboru Armii Rosyjskiej w Kubince).

24 Mirosława Świtała-Cheda (2015: 183-191) wprowadziła taki podział funkcji odnośnie do mikrotoponimów w badaniu ich pochodzenia, procesu nazwotwórczego (a więc w obszarze czysto onomastycznym).

25 Autor (Gałkowski 2018b: 136) uznaje, że przetłumaczalność onimu jest odwrotnie proporcjonalna do stopnia jego proprialności, stąd najniższą przetłumaczalność (co technicznie przekłada się na podstawienie gotowych odpowiedników uznanych - A.S.) mają onimy o najwyższym stopniu proprialności, spełniające podstawową funkcję identyfikacyjną, np. nazwy geograficzne, większość toponimów realnych, antroponimy - w tym z fikcji literackiej. Wysoki stopień - więc niską przetłumaczalność - mają przydomki, przezwiska oraz interesujące mnie szczególnie urbanonimy; tu dołącza się również sfera asocjatywna. Chrematonimy mają stopień średni, najniższy zaś w tej skali (w sumie 5 stopni) mają np. nazwy techniczne kolorów, niektóre nazwy gatunkowe. 
[...] ustanawianie odpowiednika o identycznym bądź zbliżonym (interpretacyjnym) znaczeniu w języku docelowym (w przypadku NW co najmniej znaczeniu funkcjonalnym - deiktycznym, ale także konotacyjnym i referencjalnym) [...] (Gałkowski 2018b: 136).

Obaj autorzy podkreślają wagę tych samych funkcji onimów mimo odmiennego stanowiska co do statusu działań translatorskich, skutkującego różnym ujęciem technik stosowanych w przypadku onimów, zwłaszcza innego statusu translacji jako zabiegu.

Same techniki tłumaczeniowe opisywane są w bardzo wielu klasyfikacjach, często rozbudowanych, uwzględniających wiele uszczegółowień i podziałów wewnętrznych, lub też są ujmowane bardziej ogólnie. Odwołam się wyłącznie do wybranych koncepcji, które dotyczą technik stosowanych wobec nazw własnych. Na pierwszym biegunie skali (ze względu na szczegółowość) można umieścić koncepcję Dmitrija Jermołowicza, który opisał złożoną sieć relacji pomiędzy zasadami (formalną, systemową lub odwołującą się do treści pojęcia) a metodami (czyli technikami) tworzenia odpowiedników, przy czym jedna zasada może być zrealizowana za pomocą wielu metod ${ }^{26}$. W pobliżu można by usytuować również bardzo szczegółowe zestawienia zabiegów translatorskich: Krzysztof Hejwowski wylicza siedemnaście technik (Hejwowski 2015: 176-179), Lincoln Fernandes - dziewięć (Fernandes 2006: 50-55). Gałkowski ze swoimi siedmioma sposobami tłumaczenia nazw własnych znalazłby się mniej więcej pośrodku skali (Gałkowski 2018b: 131-132) ${ }^{27}$, natomiast Lewicki - na przeciwległym biegunie, ponieważ zasadniczo wyodrębnia dwie techniki oddawania onimów: przeniesienie i tłumaczenie (2017:289-290). Warto nadmienić, że podstawą wspomnianych tu klasyfikacji był różny materiał badawczy (np. u Fernandesa materiał wyłącznie literacki, w dodatku literatura dziecięca

26 Yermolovich 2005: 167; Szczęsny 2011: 211 - adaptacja polska zestawienia.

27 Lista zabiegów jest następująca: 1) tłumaczenie etymologicznych podstaw apelatywnych nazwy; 2) tłumaczenie składników apelatywnych nazwy, których znaczenie leksykalne jest niezbędne do jej funkcjonowania; 3) dostosowanie fonetyczno-morfologiczne nazwy lub jej części do reguł formalnych języka docelowego lub zgodnie z przyjętą tradycją; 4) oddanie nazw odpowiednikami uznanymi, istniejącymi w zasobach języka docelowego; 5) cytowanie/ kopiowanie $\mathrm{w}$ formie fonetycznej (zachowanie brzmienia); transliteracja $\mathrm{w}$ tym samym lub innym alfabecie; 6) asymilacja homofoniczna; 7) adideacja, czyli nadanie odpowiednika w postaci zbliżonej formy $\mathrm{z}$ jednoczesnym wprowadzeniem nowego elementu znaczenia - gry słownej (Gałkowski 2018b: 131-132). 
z gatunku fantasy), co też jest uzasadnieniem większego lub mniejszego stopnia szczegółowości podziałów. Najważniejsze różnice pomiędzy dwiema ostatnimi koncepcjami sprowadzają się do miejsca odpowiedników uznanych: Lewicki, jak wspomniałam już wyżej, nie widzi dla nich miejsca wśród technik ${ }^{28}$, Gałkowski zaś uznaje je za transfer bezpośredni, czyli operację polegającą na „oddaniu nazw przyjętymi w onomastykonie języka docelowego odpowiednikami" (Gałkowski 2018b: 132). Ponadto w ujęciu pierwszego $\mathrm{z}$ autorów technika nazwana przeniesieniem obejmuje dość szerokie spektrum zabiegów ( $\mathrm{w}$ tym transkrypcję, transliterację, zawsze wymuszającą modyfikację czy adaptację), w ujęciu drugiego zaś - rozdziela się pomiędzy trzy techniki: adaptację fonetyczno-morfologiczną, cytowanie $\mathrm{w}$ formie fonetycznej, transliterację ( $w$ tym samym lub innym alfabecie) oraz asymilację homofoniczną. Ta druga różnica to de facto niższy lub wyższy stopień szczegółowości podziałów, a zatem i autonomiczności danej techniki. Nie wchodząc zanadto w szczegóły, odniosę się do generalizującego ujęcia Lewickiego.

Jakie są atuty ujęcia, według którego zastosowanie odpowiednika uznanego jest zabiegiem koniecznym i niepozostawiającym wyboru, poza repertuarem typowych procedur translatorskich? Po pierwsze, pozwala na unikanie niepotrzebnej lub błędnej wariantywności. Po drugie, automatycznie odpiera zarzut niekonsekwencji tłumacza, który przecież nie ma innego wyjścia. Czy jest zatem jakiś minus? Zarówno tłumacz, jak i autor tekstu wykonujący czynność paratranslatorską musi posiadać niezbędną wiedzę oraz umiejętności warsztatowe. Powinien też wiedzieć, że istnieją zabiegi konieczne do wykonania lub zaniechania. Przede wszystkim chodzi o samą świadomość, że należy najpierw szukać ekwiwalentu uznanego, a nie proponować własny (stworzony za pomocą transferu lub tłumaczenia). Ponadto w poszukiwaniu odpowiednika uznanego warto mieć na względzie egzonimy ${ }^{29}$, które dla onomastów są obiektem działań preskryptywnych,

28 „[...] jeśli nazwa własna ma ustalony w danym języku docelowym ekwiwalent, tłumacz stosuje ten ekwiwalent - i nie stoi przed żadnym wyborem" (Lewicki 2017: 275, wyróżnienie autora).

29 Warto w tym kontekście (oddawania onimów w przekładzie) sięgnąć do refleksji Włoskowicza na temat endonimów i egzonimów, który uważa za niesłuszne wyłączenie ich poza obręb onomastyki jako takiej (Włoskowicz 2021: 129-130). Bardzo ciekawe dla translatoryka i tłumacza praktyka są rozważania na temat roszczeniowości (142, 147-150), kryteriów (wspólnotowego i językowego - graficznego czy fonicznego, 150-152) odróżniania endonimu od egzonimu. Definiując egzonim, autor stwierdza: „[...] istotą egzonimiczności 
dla tłumaczy zaś źródłem potencjalnych ekwiwalentów uznanych. Sięganie do zasobów egzonimicznych może jednak postawić tłumacza przed niełatwym wyborem, jeśli są warianty (choćby ze względu na zmienność norm i uzusu w czasie ${ }^{30}$ ) lub jeśli odpowiednik uznany nie współgra $\mathrm{z}$ zamiarem komunikacyjnym tłumacza, $\mathrm{z}$ jego projektem ${ }^{31}$. Trudne też jest ustalenie z całą pewnością, co jest odpowiednikiem uznanym, jakie źródła mogą dać tłumaczowi taką pewność, kto wreszcie powinien rozstrzygać, który ekwiwalent - nomen omen - uznamy za uznany? $\mathrm{Na}$ to pytanie nie ma jednoznacznej odpowiedzi.

Z tych względów oraz z uwagi na przesłanki dydaktyczne jestem zdania, że lepiej zaliczyć podstawienie ekwiwalentu uznanego do sposobów oddawania onimów w przekładzie, pamiętając o tym, że rządzą się one innymi prawami niż przypadki dopuszczające inne rozwiązania. W mojej koncepcji triady tradycja - transfer - translacja odpowiedniki uznane znajdują się w obrębie pierwszego zakresu, niezależnie od tego, że pierwotnie były one efektem bądź to transferu, bądź translacji.

W dwudzielnym ujęciu technik Lewickiego (przeniesienie i właściwe tłumaczenie - Lewicki 2017: 190) dostrzegam cenny aspekt porządkujący: obu technikom można wszak przypisać szereg terminów podrzędnych. Ponadto za trafne uważam odniesienie ich do konkretnych grup i nawet części składowych onimów:

\section{Przeniesienie}

Właściwe tłumaczenie

nie jest ani fonia, ani tym bardziej grafia, lecz szeroko pojęta adaptacja gramatyczno-leksykalna, tj. adaptacja w zakresie fonologii, morfologii bądź słowotwórstwa lub «tłumaczenie» jako adaptacja leksykalna” (Włoskowicz 2021: 152).

30 Notabene przypadki rozpatrywane przez Gałkowskiego (Gałkowski 2018b: 132) jako adaptacje podporządkowane normom i uwarunkowaniom tradycji (jak Monteskiusz) umieściłabym w obrębie odpowiedników uznanych: to prawda, że etymologicznie były adaptacjami fonetyczno-morfologicznymi, jednak model ów jest już dziś nieproduktywny, a stylizowana latynizacja - zatarta.

$31 \mathrm{~W}$ jednej z wcześniejszych prac zwracałam uwagę (Kozłowska, Szczęsny 2018: 156-157) na niejasne w moim odczuciu kryteria ustalenia dwóch egzonimów: sobór Uspieński dla budowli sakralnej w Rostowie i sobór Zaśnięcia Matki Bożej dla budowli sakralnej we Włodzimierzu (Uchwała nr 7 KSNG z dnia 16 października 2016 r.): zastosowano dwa różne zabiegi (transfer i tłumaczenie) do eklezjonimów o tym samym wezwaniu (różnica jest widoczna w zakresie formy oficjalnej i potocznej nazw). Być może celem było zróżni- 
imiona i nazwiska (zwykle)

nazwy geograficzne (element własny)

adresy

tytuły prasowe

imiona zwierząt (zwykle)

nazwy firm i marek handlowych przezwiska

przydomki

nazwiska znaczące (zwykle)

tytuły literackie, muzyczne, dzieł sztuki

(zwykle)

nazwy geograficzne (element pospolity)

Na szczególną uwagę zasługuje element pospolity nazw geograficznych (apelatyw) wpisany do kategorii podlegającej tłumaczeniu. Rzeczywiście w kierunku tłumaczenia język obcy - język polski jest to stała technika. Co więcej, odniosłabym ją również do komponentów apelatywnych w składzie urbanonimów czy chrematonimów. Czy zawsze jednak będzie to tłumaczenie? Kiedy pożądany byłby transfer? Odniosę się do tej kwestii we wnioskach końcowych.

Na zakończenie jeszcze jedno spostrzeżenie dotyczące przeniesienia (w moim ujęciu - transferu, za Hejwowskim 2015): Lewicki uznaje, że każdemu przeniesieniu towarzyszy adaptacja fonetyczna lub morfologiczna, dlatego polemizuje m.in. z Hejwowskim, który traktował taką adaptację jako przypadek szczególny lub nawet odrębną technikę. Jeśli chodzi o adaptację fonetyczną, Lewicki (2017: 191) odwołuje się do wskazówek ortoepicznych i wniosków z praktyki tłumaczenia ustnego: za błędną uznaje się wymowę obcą, niespolonizowaną w tekście polskim ${ }^{32}$. Odnośnie do kwestii fonetycznych zgadzam się całkowicie $\mathrm{z}$ autorem.

Jeśli zaś chodzi o adaptację morfologiczną, nie do końca podzielam stanowisko Lewickiego: nie kwestionuję tego, że wyrazy przeniesione z języka obcego „wpadają" automatycznie w polskie paradygmaty, to oczywiste, zwłaszcza w szerszym kontekście wielu języków. Jeśli natomiast odnosimy

cowanie w ten sposób obiektów lub przyjęcie za punkt wyjścia eklezjonimu o największej frekwencyjności w zasobach tekstowych w języku oryginalnym.

32 Autor podaje przykład Birmingham i Richelieu - chyba jeszcze bardziej wyrazisty byłby Brueghel (plus wszystkie istniejące w polszczyźnie warianty nazwiska: Bruegel, lecz również Breugel, Breughel; nawiasem mówiąc, to też przykład szerokiego zakresu odpowiedników uznanych tego antroponimu, gdyby więc przyszło nam tłumaczyć tekst np. z języka rosyjskiego (z onimem Брейzель), byłoby nad czym się zastanawiać. Według hasła w Encyklopedii PWN obowiązuje wymowa niderlandzka, natomiast poradnia językowa PWN (post autorstwa Mirosława Bańki) opowiada się za wymową niemiecką: https://sjp. pwn.pl/poradnia/haslo/odmieniamy-Pietera-Bruegla;13145.html. To kwestia uzusu, który w ogromnej mierze kształtuje tradycję. Podobnie byłoby z nazwiskiem Van Gogh, które w wypowiedzi po polsku wymawiamy raczej z niemiecka/francuska, a nie z niderlandzka. 
się wyłącznie do materiału językowego rosyjskiego i polskiego, to jednak widzę pewien mankament, mianowicie brak odzwierciedlenia $\mathrm{w}$ takim ujęciu adaptacji morfologicznej faktu redukowania (lub zachowania) końcówek przymiotnikowych, co bywa traktowane dość arbitralnie, aczkolwiek można dostrzec prawidłowości ${ }^{33}$, które zilustruję przykładami w ostatniej, czwartej części tekstu. W analizach tych będę posługiwać się określeniami technik, które stosowałam już wcześniej ${ }^{34}$ - transfer (z modyfikacją lub bez), tłumaczenie/translacja, tradycja (odpowiednik uznany), z doprecyzowaniem charakteru modyfikacji i kombinacji zabiegów.

\section{Kompromisowe podejście do urbanonimów - pomiędzy tłumaczeniem a transferem}

Interesującym przykładem podejścia do urbanonimów (w informacjach wizualnych i systemach nawigacji w przestrzeni publicznej), a zarazem przykładem efektywnej współpracy środowiska naukowego i tłumaczy praktyków są propozycje przedstawione przez troje językoznawców z Jekaterynburga - Jekatierinę Bożko, Aleksandra Ilnera i Łarisę Korniejewą (Bozhko, Il'ner, Korneyeva 2018). Studium przypadku na materiale językowym rosyjsko-angielskim pozwoliło autorom na sformułowanie propozycji klasyfikacyjnych, odwołujących się do wymiaru funkcjonalnego urbanonimów, a następnie na sporządzenie zaleceń dla tłumaczy, szczegółowych schematów postępowania dla konkretnych grup urbanonimów, wyodrębnionych na podstawie kryteriów semantyczno-funkcjonalnych oraz gramatyczno-strukturalnych. Ramy niniejszego artykułu nie pozwalają na szczegółowe omówienie projektu, jednak przytoczę najważniejsze ustalenia oraz kilka przykładów, ponieważ w moim przekonaniu pewne rozwiązania mogłyby się dobrze sprawdzić na gruncie onomastyki przekładowej w parze językowej rosyjski - polski oraz polski - angielski.

Na czym przede wszystkim polega kompromisowe podejście do nazewnictwa miejskiego w przekładzie? Autorzy stoją na stanowisku, że wybór pomiędzy dwoma sposobami oddawania urbanonimów w przestrzeni infor-

33 W nazwach stacji metra z niezredukowaną końcówką w transkrypcji, w nazwiskach i nazwach ulic - częściej bez końcowego - j lub -ja.

34 (Szczęsny 2011, 2017, 2019; Kozłowska, Szczęsny 2018). 
macyjnej (kontekst ten ma zasadnicze znaczenie) - pomiędzy tłumaczeniem respektującym normy języka docelowego a transferem (transliteracją) - nie wyczerpuje listy możliwych technik, a poza tym może stanowić poważne ograniczenie w komunikacji dwujęzycznej (Bozhko, Il'ner, Korneyeva 2018: 223-224). Szczególnie kłopotliwymi do transliterowania komponentami urbanonimów są liczebniki (wyrażone słownie) oraz akronimy, a także funkcjonujące tradycyjne odpowiedniki uznane antroponimów o szerokim zakresie rozpoznawalności - te ostatnie $\mathrm{z}$ definicji burzą zasadę jedności techniki, ponadto:

[...] Istnieje tradycja transliterowania nazwisk pochodzących z innych kultur. Jednak oddanie ich jako składowych toponimu za pomocą transliteracji prowadzi do dysonansu poznawczego i braku zrozumienia interkulturowego (Bozhko, Il'ner, Korneyeva 2018: 225, przekład - A.S.) ${ }^{35}$.

Technika kalki, czyli tłumaczenia, dobrze się sprawdza w środowiskach naturalnie wielojęzycznych czy dwujęzycznych, natomiast nie wydaje się autorom pożądana na obszarach monolingwalnych.

Omawiając właściwości strukturalne urbanonimów, istotne z punktu widzenia ich oddania w języku angielskim, autorzy odwołują się do koncepcji Jermołowicza (Yermolovich 2005: 269) i uznają, że najważniejsze ich składniki znaczenia to komponent klasyfikujący oraz indywidualizujący, które przekładają się na konkretne części urbanonimu:

1. część statusowa (статусная часть), najczęściej termin ogólny (analogia apelatywu w nazwach geograficznych), np. площадь, улица, парк ('plac, ulica, park');

2. część zasadnicza ${ }^{36}$ (основная часть), czyli wszystkie inne składowe poza określeniem statusu (Bozhko, Il'ner, Korneyeva 2018: 226) (площадь) Труда, (парк) Победы ('plac Pracy', 'park Zwycięstwa').

Autorzy podkreślają, że w przypadku niektórych obiektów miejskich najważniejsza jest ich funkcja w infrastrukturze miasta, zatem ich wartość

35 „Традиция транслитерировать имена из других культур существует. Однако их передача в составе топонимов с помощью транслитерации приводит к когнитивному диссонансу и межкультурному непониманию" (Bozhko, Il'ner, Korneyeva 2018: 225).

36 Ta dychotomia część statusowa/część zasadnicza przypomina podział strukturalny nazw geograficznych na termin rodzajowy i termin wyróżniający w nazwie geograficznej. 
komunikacyjna jest szczególnie istotna. Tak więc czynnik rangi obiektu będzie decydować o wyborze techniki tłumaczeniowej dla konkretnego urbanonimu. Ważne jest, by nazwa w języku obcym pozwoliła cudzoziemcowi z łatwością zidentyfikować ${ }^{37}$ obiekt, np. taki jak szpital czy dworzec kolejowy, przystanki komunikacji miejskiej w ich pobliżu noszące tę samą nazwę itd. (Bozhko, Il'ner, Korneyeva 2018: 228-229).

Z kryterium denotacyjno-funkcjonalnego wynika podział obiektów na kluczowe i drugorzędne, przy czym - co zasługuje na szczególne podkreślenie - w przypadku każdego miasta lista tychże może być inna.

Uniwersalny charakter mają natomiast zasady ogólne tworzenia odpowiedników obcojęzycznych (tu: anglojęzycznych): jeżeli obiekt należy do kluczowych, w przypadku takiej nazwy powinno być stosowane tłumaczenie (kalka), natomiast jeżeli obiekt nie należy do kluczowych, należy zastosować transliterację lub metodę hybrydową.

Ważną konkluzją wydaje mi się dopuszczalność dubletów: w przypadku ulicznych informacji wizualnych czy nazw na planie miasta raczej jest to mało możliwe, natomiast w zasobach elektronicznych czy w przewodnikach warto stosować dublet, np.: Музей истории Екатеринбурга - Ekaterinburg History Museum / Muzei Istorii Ekaterinburga (Bozhko, Il'ner, Korneyeva 2018: 228-229). Jestem przekonana, że tę regułę byłoby warto stosować w parze językowej rosyjski - polski.

Ze względu na specyficzne trudności, zarówno o charakterze semantycznym, jak i strukturalnym, autorzy wyodrębnili sześć grup urbanonimów, którym przypisali odpowiednie schematy postępowania (zwykle trzy- lub czteroetapowe). Trudności z oddaniem urbanonimów w języku angielskim mogą być formalno-strukturalne (liczebniki oraz akronimy) lub językowo-kulturowe (antroponimy w składzie nazwy, mające odpowiedniki uznane). Są ponadto problemy, które wynikają z relacji międzyjęzykowych: po transliteracji urbanonimu rosyjskiego na angielski mogą się w nim znaleźć wyrazy lub morfemy analogiczne do angielskich (to przypadek prosty do

37 Twórcy „kompromisowego podejścia” są zdania, że w ich przypadku transliteracja nie pomoże anglojęzycznemu cudzoziemcowi, jako że kanał słuchowy będzie niewystarczająco pomocny w nawigowaniu. Akurat ten problem, już poza kontekstem tablic informacyjnych w mieście, lecz np. w przewodnikach elektronicznych lub na mapach interaktywnych (z elementami multimedialnymi), mogłaby rozwiązać specjalna aplikacja na smartfony, odsyłająca do stosownych plików dźwiękowych będących zapisem konkretnych urbanonimów - najlepiej $\mathrm{w}$ ich wersji potocznej, obiegowej, maksymalnie ułatwiającej orientację. Być może takie rozwiązanie niebędące de facto tłumaczeniem sprawdzi się w przyszłości? 
rozwiązania - autorzy sugerują użycie anglicyzmu), homografy wyrazów angielskich, mających inne znaczenie w obu językach, wreszcie - homografy angielskich wyrazów substandardowych. W dwóch ostatnich przypadkach niezbędna jest korekta tego elementu nazwy.

Dostosowując powyższy podział do pary językowej rosyjski - polski, uznałabym za przypadki szczególnie trudne nazwy obiektów zawierające antroponimy (związane $\mathrm{z}$ kulturą rosyjską lub z trzecią kulturą) oraz zawierające akronimy.

Z kolei w przypadku grup, wyróżnionych ze względu na homonimię/homografię międzyjęzykową, proponowane przez autorów procedury sprawdzą się z powodzeniem w tłumaczeniu z języka polskiego na angielski.

Charakterystyczne jest, jak dużą wagę ma dla autorów kwestia ewentualnych niepożądanych konotacji nazwy przetransliterowanej. Wcześniej pisał o tym m.in. Jermołowicz na przykładzie antroponimów, zarówno w kontekście literackim, jak i użytkowym ${ }^{38}$. Z tego względu jednym $\mathrm{z}$ kroków w tym schemacie jest przeszukiwanie angielskich słowników slangu, dostępnych online, a także sprawdzenie w brytyjskim korpusie narodowym (Bozhko, Il'ner, Korneyeva 2018: 233-234), czy wyraz rosyjski w transliteracji angielskiej nie ma przypadkiem znaczenia, które może budzić jakiekolwiek niewłaściwe (ośmieszające lub obsceniczne) skojarzenie. Lewicki (2017: 286-287) na przykładach zaczerpniętych z języka polskiego i rosyjskiego również zwraca uwagę na ten aspekt, podkreśla także trudności w wymowie jako czynnik wymuszający korektę nazwy oddanej za pomocą transferu.

Opisane procedury zilustruję dosłownie jednym przykładem (Bozhko, Il'ner, Korneyeva 2018: 231-232): będzie to schemat proponowany w przypadku urbanonimów zawierających antroponimy. Obejmuje on następujące kroki:

1. ustalenie stopnia rozpoznawalności antroponimu zawartego w urbanonimie (znany powszechnie czy lokalnie);

2. ustalenie, czy antroponim ma w języku docelowym ekwiwalent uznany, tradycyjny bądź regularnie stosowany ${ }^{39}$; jeśli tak, to należy

38 Jermołowicz przywołuje przykład antroponimu Шитиков: to nazwisko wysoko postawionego działacza KPZR w latach 70. XX wieku w tekstach agencji informacyjnych zapisywano nie Shitikov, lecz Chitikov, więc niezgodnie z transliteracją angielską - wszystko po to, by uniknąć obscenicznych konotacji (Yermolovich 2001: 27).

39 Autorzy odsyłają do wyszukiwarek konkretnych korpusów języka angielskiego: COCA - Corpus of Contemporary American English i BNC - British National Corpus. 
wybrać ten o największej frekwencyjności, jeżeli nie, zastosować transkrypcję (tzw. praktyczną ${ }^{40}$ );

3. uwzględnienie - lub też nie ${ }^{41}$ - końcówki przypadkowej antroponimu.

Ta ostatnia reguła wymaga $\mathrm{w}$ moim przekonaniu doprecyzowania: końcówka przypadkowa (najczęściej dopełniacza) jest naturalna w języku źródłowym rosyjskim i innych fleksyjnych, lecz niekoniecznie w innym języku, z którego pochodzi nazwisko, zaadaptowane przez system języka rosyjskiego.

Zgodnie z przedstawionymi regułami hodonim улица Готвальда otrzymuje odpowiednik ulitsa Gottwalda - w tym przypadku autorzy postulują zachowanie końcówki dopełniacza, powołując się na normy języka rosyjskiego. Uważam to uzasadnienie za niewystarczające, zwłaszcza w kontekście kontrprzykładu podanego dalej. Kluczowe wydaje mi się nie tyle funkcjonowanie nazwiska w języku rosyjskim, ile we właściwym języku źródłowym, tu czeskim, w którym również się ono odmienia. Gdyby decydujące w tym rozstrzygnięciu miały być jedynie normy języka rosyjskiego, to trudno byłoby uzasadnić odmienną decyzję autorów projektu w odniesieniu do nazwiska Patrice Lumumba (propozycja: ulitsa Patrice Lumumba), które wszak odmienia się w rosyjskim (улииа Патриса Лумумбы ), lecz jest nieodmienne (z oczywistych powodów) we francuskim. To jednak szczegół do dopracowania, natomiast na gruncie pary językowej rosyjski - polski, z możliwym odwołaniem do tzw. trzeciej kultury i trzeciego języka, warto zawsze pamiętać o prymacie odpowiednika uznanego antroponimu, wchodzącego w skład urbanonimu.

Reasumując, najistotniejsze w omówionym wyżej projekcie wydają mi się trzy kwestie, porządkujące i systematyzujące zagadnienie urbanonimów w tłumaczeniu:

- stosowanie jednolitej, ściśle określonej, stałej techniki w stosunku do statusowej (apelatywnej) części urbanonimu: w parze rosyjski - angielski to transliteracja, z kilkoma wyjątkami) - w parze rosyjski polski postulowałabym translację, z zastosowaniem stałego odpowiednika słownikowego (ekwiwalentu konwencjonalnego);

40 Zgodną z zasadami z publikacji Duplenskiy 2015, Yermolovich 2005.

41 Autorzy postulują unikanie formy przypadka zależnego, wyrażonego końcówką fleksyjną, jeżeli zmieniłoby to właściwości foniczne i graficzne owej nazwy osobowej (czyli utrudniłoby rozpoznawalność - A.S.). 
- określenie rangi obiektu oznaczanego przez urbanonim (kluczowy czy drugorzędny) i przypisanie mu konkretnej techniki;

- określenie typu strukturalno-semantycznego urbanonimu, odniesienie do właściwej grupy i zastosowanie przypisanego do niej sche$\mathrm{matu}^{42}$.

Chciałabym również podkreślić wagę współpracy pomiędzy językoznawcami translatorykami a tłumaczami, a także rolę zunifikowanych (zalecanych przez Narodową Ligę Tłumaczy i Związek Tłumaczy Rosji), na bieżąco nowelizowanych rekomendacji dla tłumaczy, które mają u swych źródeł nie tylko informacje zaczerpnięte z praktyki rynkowej, z prac państwowych lub regionalnych komisji toponimicznych, lecz również podstawy naukowe (przede wszystkim monografie Jermołowicza). Co więcej, uczelnie kształcące tłumaczy również włączają owe wskazówki do swoich programów i zasobów dydaktycznych. Taka wymiana doświadczeń z pewnością służy systematyzacji i unifikacji onomastykonu w praktyce translatorskiej.

\section{Nazwy własne w przestrzeni miejskiej w dydaktyce tłumaczenia - problemy, propozycje ćwiczeń}

Pejzaż językowy ${ }^{43}$ miasta, a szczególnie obecne w nim nazwy własne, to również wartościowy materiał dla dydaktyki przekładu. W tekstach opisujących miasta zawarte są onimy mające bezdyskusyjne ${ }^{44}$ (?) odpowiedniki uznane, jak np. Невский проспект - Newski Prospekt, a także odpowiedniki niestabilne, tzn. dopuszczające konkurencyjne rozwiązania, uzależnione

42 Jeśli urbanonim nie mieści się w żadnej z wyodrębnionych grup, stosuje się jeszcze inną technikę (tu: praktyczną transkrypcję).

43 Zob. Guy Puzey 2016: 395-421.

44 Zmienność przyjętych reguł może prowadzić do sytuacji, w której grupa nazw ma odpowiedniki ustalone wcześniej w innym zapisie (jak np. Dworzec Białoruski i pozostałe główne dworce kolejowe w Moskwie - zob. Zmiany wprowadzone na XXXI posiedzeniu Komisji Standaryzacji Nazw Geograficznych 21 marca 2007 r.), a kolejna grupa analogicznych nazw podlega już innym zasadom (jak np. dworzec Ładoski i inne dworce kolejowe w Petersburgu - zob. Uchwała KSNG nr 7/2016 z dnia 19 października 2016 r.). Nazwy dworców moskiewskich nie zostały zmienione. Natomiast ezgonim Ogród Aleksandrowski, ujęty we wspomnianym protokole z 94 posiedzenia Komisji, został następnie dostosowany do zasad ortograficznych języka polskiego na 111 posiedzeniu Komisji w dniu 2 grudnia 2020 r.: ogród Aleksandrowski. Na temat trudności ortograficznych w onomastykonie miejskim zob. Kozłowska, Szczęsny 2018: 154-155. 
od strategii obranej przez tłumacza. Ze względu na onomastykon miejski ciekawe są teksty poświęcone rewitalizacji. Obok nazw uświęconych tradycją występują w nich onimy oznaczające obiekty historyczne, które zmieniły swoje pierwotne przeznaczenie i otrzymały nazwy nawiązujące do przeszłości lub zupełnie $\mathrm{z}$ nią niezwiązane. Pojawiają się także nazwy miejsc o zupełnie nowych funkcjach, a ponieważ dzieje się to w ramach trendu ogólnoświatowego, często nazwy te zawierają słowa lub elementy obcojęzyczne, przede wszystkim pochodzące z języka angielskiego. Nawiasem mówiąc, ta tendencja nazewnicza wpisuje się w wielojęzyczność ${ }^{45}$ współczesnego pejzażu językowego. To zjawisko dość powszechne od kilku dziesięcioleci, a że dotyczy również Polski oraz krajów rosyjskojęzycznych (te właśnie kontakty językowe są przedmiotem moich badań), warto wypracować rekomendacje dla tłumaczy, uwzględniające specyficzną rolę angielszczyzny.

Moje przemyślenia zaprezentowane poniżej nie stanowią ustrukturyzowanej koncepcji, to raczej przyczynek do praktycznej onomastyki przekładowej i pole do dalszych dyskusji. Na temat trudności, z jakimi wiąże się dobrze umotywowane dydaktycznie wprowadzenie problematyki nazw własnych do zajęć warsztatowych z tłumaczenia pisemnego, pisałam niejednokrotnie wcześniej ${ }^{46}$. Punktem wyjścia jest zazwyczaj szczegół - analiza pojedynczych nazw własnych, natomiast przejście do ogółu - syntezy, nie jest bynajmniej proste. Może się okazać, że przykłady rozwiązań zawartych w jednym tekście, przetłumaczonym z języka wyjściowego na docelowy lub też napisanym w języku docelowym, a uwzględniającym onimy pochodzące z języka „wyjściowego" ${ }^{47}$, stoją w sprzeczności z zasadą konsekwentnego

45 Ciekawe przykłady z Helsinek w latach 2016-2017 - współistnienie języka fińskiego, szwedzkiego oraz angielskiego w miejskiej przestrzeni informacyjnej - opisała Kartushina (2017: 73-75). Autorka badała szeroko rozumiany pejzaż językowy, czyli komunikaty w sferze życia codziennego. Jasne jest, że status tych trzech języków oraz ich wzajemne relacje są różne, natomiast rola angielskiego przynajmniej częściowo jest podobna, jeśli chodzi o urbanonimy polskie czy rosyjskie. Sytuację nazewnictwa (Places-names) w kontakcie językowym opisuje B. Sandnes (2016: 542-549), zwracając uwagę na aspekt historyczny i aktualny, a postrzega je przez pryzmat różnorakich adaptacji (fonologicznej, morfologicznej, składniowej, semantycznej - tłumaczenia, leksykalnej), wyodrębnia też nazwy hybrydowe.

46 Zob. m.in. (Szczęsny 2011, 2017) - o technikach i ich podporządkowaniu projektowi przekładowemu, (Szczęsny 2019: 88-89,94-95) - o stopniowaniu problemów w ramach kursu podstaw przekładu pisemnego oraz warsztatów bardziej zaawansowanych.

47 Cudzysłów podkreśla fakt, że nie chodzi o tłumaczenie jako takie, a o działania paratranslatorskie: autor tworzy swój tekst traktujący o rzeczywistości i kulturze obcej, związanej z określonym językiem, z którego musi zaczerpnąć m.in. nazwy własne. Jest to zagadnienie 
stosowania technik. Marina Zagidullina i Swietłana Krajewa (Zagidullina, Krayeva 2019: 68), przeprowadzając analizę tłumaczeń studenckich pod kątem antroponimów (dyskurs medialny, kierunek tłumaczenia: niemiecki rosyjski), podkreślają wagę owej reguły, a także jej wymiar etyczny (nienaruszalność tekstu wyjściowego):

Z naszego punktu widzenia największym problemem jest aspekt etyczny sytuacji, w której początkujący tłumacz nie waha się stosować różnych strategii do oddania imienia i nazwiska tej samej osoby lub różnych osób opisanych obok siebie w tekście, łamiąc tym samym zasadę jednolitości oddawania analogicznych jednostek przekładu. [... [ Niewątpliwie decyzja dotycząca adaptacji antroponimu, by brzmiał on bardziej znajomo, może być uzasadniona jego funkcją w tekście oraz funkcją tekstu przekładu w ogóle (przekład - A.S.) ${ }^{48}$.

Jest to reguła szalenie trudna lub wręcz niemożliwa do praktycznego zastosowania, skoro w opisie sąsiadują ze sobą nazwy obiektów o identycznym statusie, czyli takie same ,jednostki tłumaczeniowe”, lecz niektóre z nich mają w języku docelowym swój odpowiednik uznany, a inne - nie. Dążenie do jednolitości rozwiązań uwzględniających odbiorcę, cel komunikacji, wymiar funkcjonalny tekstu zderza się, często kosztem owej jednolitości, z uzusem. Poza tym skoncentrowanie się, być może nadmierne, na technikach oddawania onimów w przekładzie na gruncie języka rosyjskiego i polskiego wynika $\mathrm{w}$ dużej mierze z bariery, jaką stanowią różne alfabety, oraz z konieczności wyboru pomiędzy konkurencyjnymi zabiegami translatorskimi. W ramach zajęć z podstaw przekładu pisemnego stosuję kilkuetapowe wprowadzanie studenta w problematykę onimów. W przykładach ilustrujących poszczególne etapy skoncentruję się na urbanonimach i chrematonimach.

dobrze znane historykom zajmującym się źródłami w języku obcym, szczególnie o innym alfabecie (moja publikacja na ten temat na materiale języka rosyjskiego - w przygotowaniu do druku).

48 „Наиболее проблемным однако здесь нам видится этический аспект, когда начинающий переводчик не стесняется использовать разные стратегии для передачи имени и фамилии одного и того же человека или имен двух людей, стоящих рядом в тексте, в нарушение принципа единообразия передачи аналогичных единиц перевода. [...] Безусловно, решение об адаптации антропонима, чтобы он звучал более знакомо, может иметь свои основания, в зависимости от его функции в тексте и функции самого текста перевода" (Zagidullina, Krayeva 2019: 68). 
Etap 1. Analiza urbanonimów określających obiekty z rzeczywistości rosyjskiej w tekstach napisanych po polsku, niebędących tłumaczeniami sensu stricto.

Etap 2. Praca nad urbanonimami jako przygotowanie do tłumaczenia tekstu, w którym są one zawarte (można oczywiście poprzestać na ich opracowaniu).

Etap 3. Ćwiczenie podsumowujące - tłumaczenie krótkiego tekstu ze znaczną liczbą różnorodnych urbanonimów.

Ad 1. Zadanie studentów polega na określeniu funkcji tekstowej spolszczonych urbanonimów w analizowanym tekście niebędącym tłumaczeniem sensu stricto, na odnalezieniu potencjalnych/domniemanych urbanonimów oryginalnych w języku „wyjściowym”, czyli rosyjskim, wreszcie na zdefiniowaniu zabiegów paratranslatorskich/technik tłumaczeniowych zastosowanych (świadomie lub nie) przez autora tekstu w odniesieniu do wskazanych nazw. Takie ćwiczenie ma na celu zrozumienie konkretnej techniki i decyzji autora/tłumacza, a także pogłębioną refleksję metatranslatorską, uwzględniającą funkcjonowanie onimu w tekście docelowym.

Przed przystąpieniem do tłumaczenia tekstu o zmianach w pejzażu Petersburga w latach 2009-2019 studenci analizują różne teksty autorów polskich o tym mieście - od krótkich prasowych do dokumentalistyki. Analizie poddano szereg urbanonimów z książki Joanny Czeczott Petersburg. Miasto snu. Notabene niektóre $\mathrm{z}$ nich okazały się przydatne $\mathrm{w}$ toku pracy nad właściwymi tekstami do tłumaczenia.

\section{Wybrane przykłady}

Jeśli chodzi o hodonimy, nie ma stabilnego modelu, jednak widać starania autorki o jednolitość tekstu:

- ekwiwalent uznany (zarazem egzonim odnotowany w uchwałach KSNG): Newski Prospekt, Nabrzeże Pałacowe;

- transfer z modyfikacją morfosyntaktyczną (adaptacja końcówki i szyku): prospekt Smolny, bulwar Wokzalny, bulwar Mytniński, ulica Milionna;

- transfer z modyfikacją syntaktyczną (adaptacja szyku), bez morfologicznej: ulica Szpalernaja, ulica Pierwaja Krasnoarmiejskaja;

- transfer z modyfikacją morfologiczną (ucięcie końcówki), bez syntaktycznej: Bolszoj Sampsoniewski Prospekt;

- transfer bez modyfikacji: prospekt Niepokorionnych. 
We wszystkich powyższych przypadkach możemy uznać, że komponent statusowy (czyli apelatywny) nazwy został przetłumaczony za pomocą ekwiwalentu słownikowego, natomiast komponent zasadniczy poddano operacji transferu (transkrypcji), z modyfikacjami lub bez. W tekście wśród hodonimów zdecydowanie dominują te z modyfikacjami. Oczywiście poza (ponad?) nimi znajdują się odpowiedniki uznane, tu egzonimy, respektujące tradycję.

W przypadku nazw stacji metra można zaobserwować dominację funkcji lokalizującej: stacja Staraja Dieriewnia, stacja Dostojewskaja, Mieżdunarodnaja, Wołkowskaja, a najczęstsza technika to transfer (transkrypcja) komponentu zasadniczego bez modyfikacji (pozostaje końcówka). Ma to swoje uzasadnienie funkcjonalne, formalnie zbliża się do rozwiązań takich jak na dwujęzycznych tablicach informacyjnych, jest łatwe do skojarzenia $\mathrm{z}$ nimi przez użytkownika języka polskiego, a zarazem nie razi niepotrzebną obcością w tekście reportażu ${ }^{49}$. Gdyby jednak kontekst był inny, np. opis trasy wycieczki, to nawet zastosowanie transliteracji angielskiej w tekście polskim w odniesieniu do ważnych punktów orientacyjnych (lub też dubletu, jeśliby miejsce na to pozwalało) byłoby rozwiązaniem w moim przekonaniu akceptowalnym.

W przypadku dwu dosłownie nazw autorka książki wybrała inne rozwiązanie: chodzi mianowicie o stację Kanał Obwodowy i stację Instytut Technologiczny ${ }^{50}$. Można zadać sobie pytanie, czemu uległa pokusie translacji (której zresztą często ulegają tłumacze, dostrzegając w nazwie własnej element znaczący). Uzasadnienia mogą być co najmniej dwa: po pierwsze, uda się bez trudu, nawet w wersji przetłumaczonej, skojarzyć nazwy z napisami w transliteracji angielskiej, zatem spełnią one swoją funkcję punktów orientacyjnych. Po drugie, odpowiada to zasadzie zaproponowanej w omówionym wyżej projekcie jekaterynburskim, zgodnie z którą nazwa przystanku komunikacji miejskiej powinna mieć oznaczenie tożsame z obiektem, w którego pobliżu jest zlokalizowana. Jeśli poza tym uznamy, że jest to obiekt $\mathrm{z}$ grupy kluczowych, translacja jest dobrze umotywowanym zabiegiem.

Bardzo ciekawy okazał się przypadek jednego teatronimu, ponieważ dobrze ilustruje zagadnienie ekwiwalentu uznanego. W analizowanej książce pojawia się dwukrotnie, za każdym razem w innej wersji: Teatr Mariński

49 Zob. np. interaktywną mapę metra petersburskiego z nazwami każdej stacji po rosyjsku i w transliteracji angielskiej: Staraya Derevnya, Dostoyevskaya, Mezhdunarodnaya, Volkovskaya.

50 W wersji z mapy: Obvodny Kanal, Tekhnologicheskiy Institut. 
(s. 187) oraz Teatr Maryjski (s. 280). Weryfikacja tekstów paralelnych w języku polskim, poza wariantem Teatr Maryjski (Encyklopedia PWN online, artykuł w czasopiśmie „Murator plus”), przyniosła jeszcze jedną wersję: teatr Maryjski - na stronie KSNG, na liście zmian egzonimów z 2016 roku. Jakie wnioski można wysnuć na podstawie tych trzech rozwiązań? Warto zacząć od końca:

- egzonim zawarty w dokumentach KSNG możemy utożsamić z ekwiwalentem uznanym, począwszy od wprowadzenia korekty ortograficznej - zatem w wersji teatr Maryjski staje się obowiązujący od roku 2016;

- odpowiednik Teatr Maryjski w poprzedniej wersji ortograficznej może być uznany za poprawny w tekstach stworzonych i przetłumaczonych przed uchwaleniem zmiany;

- wariant Teatr Mariński, utworzony za pomocą transferu (transkrypcji z modyfikacją), w tym momencie należy uznać za przykład niewłaściwego zastosowania techniki tłumaczeniowej, skoro istnieje już odpowiednik uznany. Do wykonania ćwiczenia w etapie 2 posłuży zatem aktualny odpowiednik uznany, wymieniony tu jako pierwszy.

Ad 2. Zadanie studentów polega na określeniu funkcji onimów w tekście wyjściowym (rosyjskim), a następnie - w tekście docelowym (polskim), zgodnie z koncepcją Lewickiego (2017: 267-8). Ponieważ funkcje te mogą być różne, właściwe ich zdefiniowanie wpłynie na dobór technik, pozwoli uzasadnić wybór jednego rozwiązania spośród kilku potencjalnych. Uważam, że konieczna jest gradacja zadań „technicznych”: od przykładów prostych w mikrokontekście (jedno zdanie, akapit) do przykładów bardziej skomplikowanych, niejednoznacznych. Warto tak dobrać materiał tekstowy, by wymagał on zastosowania co najmniej dwóch, a nawet trzech technik, co wiąże się z koniecznością uzasadnienia wyboru poprzez określenie czytelnika projektowanego. Zadanie kończy się bądź sporządzeniem listy onimów wraz z ich odpowiednikami, dobranymi do potrzeb konkretnego przekładu, bądź dodatkowo tłumaczeniem fragmentów (krótkich tekstów) zawierających onimy.

\section{Wybrane przykłady}

Улиц, Рубинитейна - taki hodonim znalazł się w tekście (w którym notabene był także omówiony wyżej teatronim) opisującym historię i znaczenie 
tej ulicy dla petersburżan. Jest to przypadek nieco trudniejszy, ponieważ nazwa reprezentuje kod memoratywny (pamiątkowy) i ma w swym składzie antroponim. Sam tekst dostarcza informacji o patronie ulicy, więc analiza kulturowa może się ograniczyć do tego jednego tekstu. Pozostaje rozstrzygnięcie formy zapisu antroponimu zawartego w hodonimie. Są trzy możliwości do rozważenia: transkrypcja z rosyjskiego (Rubinsztejn), forma wyjściowa (jak w języku niemieckim), (Rubinstein) lub też forma spolszczona (Rubinsztajn). Ze względu na częstotliwość zapis drugi można uznać za naturalny wybór, natomiast dwie pozostałe formy również można uzasadnić: pierwsza, przetranskrybowana, podkreśla związek kompozytora i dyrygenta z Petersburgiem, ostatnia zaś jest wyraźnym spolszczeniem. Precyzyjne określenie adresata tekstu determinuje wybór rozwiązania.

Znacznie trudniejsze do opracowania urbanonimy (a zarazem chrematonimy - ergonimy, instytucjonimy) znajdowały się w krótkich tekstach poświęconych rewitalizacji. Z nich pochodzą kolejne przykłady.

Дизайн-завод «Флакон» - praca nad propozycją odpowiednika tego onimu jest znacznie bardziej złożona. Po pierwsze, wymaga analizy kulturowej, czyli zasięgnięcia wiedzy na temat przeszłości tego zrewitalizowanego obiektu, by zaproponować jak najlepsze rozwiązanie dla części zasadniczej nazwy («Флакон»). Po wykorzystaniu tekstu źródłowego oraz tekstów paralelnych na temat desygnatu i ustaleniu, że chodzi o dawną fabrykę opakowań szklanych (w tym flakoników na perfumy), pozostaje podjęcie decyzji, czy wybieramy transkrypcję - Fłakon, czy może lepszym rozwiązaniem będzie jeszcze lepiej kojarzące się z historią miejsca użycie odpowiednika słownikowego - Flakon. Sądzę, że ta druga wersja spełnia wymogi zarówno informacyjne (funkcja kulturowa), jak i dające orientację w przestrzeni (funkcja lokalizująca). Pozostaje komponent statusowy, czyli дизайн-завод. Tu znów konieczne jest odwołanie się do rzeczywistości pozajęzykowej, tym razem po to, by dowiedzieć się więcej o charakterze obiektu, o istocie jego obecnej działalności. Sam tekst źródłowy przychodzi z pomocą, podpowiadając synonimy: арт-кластер, творческий кластер, креативное пространство. Rozwiązań jest więc kilka: można sięgnąć do wyrażenia angielskiego art cluster, funkcjonującego w tekstach polskich $\mathrm{w}$ analogicznej roli, można zaproponować translację któregokolwiek $\mathrm{z}$ jego synonimów, np. przestrzeń twórcza, przestrzeń kreatywna ${ }^{51}$. W pracy jednej

51 Wyrażenia takie występują w polskich ergonimach (instytucjonimach), a funkcje 
ze studentek pojawiła się ciekawa propozycja fabryka kreatywności, dobrze oddająca skojarzenie historyczne. Najistotniejsze jest uświadomienie sobie funkcji, jaką ma spełnić analizowany onim w tekście docelowym: połączyć w sobie odwołanie do historii i do współczesnego oblicza miejsca, związanego ze sferą działalności twórczej.

Niewątpliwie warte uwagi są również urbanonimy, które w warstwie formalnej można zaliczyć do realizacji ksenokodu (za Szmielową - Shmelëva 2019), ponieważ wymagają przeanalizowania roli elementów obcych i znalezienia rozwiązań, w których możliwe lub pożądane jest zastosowanie języka angielskiego. Spotkamy w tej grupie urbanonimów (zarazem instytucjonimów jak wyżej) ciekawe hybrydy nazewnicze, w których elementy angielskie zapisane są łacinką bądź cyrylicąą2.

\section{Антикафе Local Time ("Локал Тайм»)}

W tym przypadku proponowane rozwiązanie jest stosunkowo proste: Antykawiarnia Local Time. Więcej uwagi wymagała część statusowa - możemy ją oddać, korzystając z coraz liczniejszych chrematonimów polskich określających podobne miejsca: antykawiarnia lub antycafe ${ }^{53}$ (ta druga w polskich zasobach jest stosunkowo rzadka). Część zasadniczą nazwy zdecydowanie należy pozostawić w formie źródłowej, czyli angielskiej, transfer (czyli transkrypcja polska transkrypcji rosyjskiej) nie ma sensu.

\section{Антикафе \& Коворкинг Хорошая Республика}

Poszukując dobrego odpowiednika, warto skorzystać ze schematu przedstawionego powyżej: część apelatywną (statusową) nazwy możemy oddać poprzez analogiczne: antykawiarnia i przestrzeń coworkingowa - to wersja bardziej spolszczona, $\mathrm{z}$ derywatem rzeczownika angielskiego, lub też antykawiarnia \& coworking - to z kolei wersja mniej zaadaptowana, z elementem całkowicie obcym. Pozostaje jeszcze komponent właściwy: tu ze względu na funkcję lokalizującą, wbrew wersji anglojęzycznej na stronie kawiarni i w jej

nazywanych obiektów są analogiczne.

52 Bardzo rozbudowane studium na temat złożonych relacji elementów obcych i swojskich w urbanonimach, ze szczególnie interesującym opisem hybrydyzacji graficznych - kombinacji alfabetów, przedstawiły J. Riemczukowa i T. Sokołowa (Remchukova, Sokolova 2019).

53 Zob. np. Antycafe Klubokawiarnia Bez Widoków - https://www.facebook.com/Antycafe-Klubokawiarnia-Bez-Widok\%C3\%B3w-156632511039962/?rf=201864636515399 lub AntyCafe PozaCzasem - https://www.facebook.com/antycafe/. 
adresie (Good Republic), lepszym rozwiązaniem wydaje się transkrypcja: Choroszaja Riespublika.

Арт-кафе «Рукав»

O ile część statusowa nie będzie sprawiała problemu - znów można zastosować analogiczny zabieg jak wyżej, czyli poszukać odpowiednika funkcjonalnego (kawiarnia artystyczna) lub skorzystać z uzusu nazewniczego (wiele lokali gastronomicznych ma w swojej nazwie składnik art cafe, bardzo różnie zapisywany) - o tyle część właściwa nie powinna być automatycznie transkrybowana (jako Rukaw), wymaga sięgnięcia do „encyklopedii” (za Cieślikową 2011), by ustalić motywację nazwy. Twórcą i patronem tej przestrzeni kreatywnej jest rzeźbiarz Aleksandr Rukawisznikow, od jego nazwiska pochodzi nazwa. Ponieważ jako artysta znany jest w sieci pod swoim nazwiskiem w transliteracji angielskiej Rukavishnikov, warto zrezygnować z naturalnej w podobnych przypadkach transkrypcji zgodnej z polską normą i użyć właśnie transliteracji angielskiej: kawiarnia artystyczna Rukav lub Art Cafe Rukav.

Клуб Газгольдер

Nazwa tego urbanonimu wiąże się z przeszłością zrewitalizowanego obiektu (niegdyś mieściła się tam gazownia) i pochodzi od angielskiego gas holder. W tym przypadku możliwości są dwie: przetłumaczona część statusowa z wersją angielską części zasadniczej klub Gasholder lub też z jej transkrypcją - klub Gazgolder. Za tym drugim rozwiązaniem przemawia nazwa podana na stronie domowej instytucji: Gazgolder Club \& Tea Room oraz fakt, że słowo газгольдер jest dawnym zapożyczeniem, funkcjonującym w języku rosyjskim w znaczeniu 'zbiornik na gaz'.

Przytoczone tu przykłady (nazwy kawiarni - przestrzeni artystycznych) pokazują, że transliteracja angielska może mieć zastosowanie przy tworzeniu odpowiedników urbanonimów rosyjskich w tekstach polskich, przede wszystkim dlatego, że jest szczególnie pomocna w realizacji funkcji lokalizującej (identyfikującej). Być może nawet warto wykorzystać w tekstach użytkowych o dominującej funkcji lokalizującej oficjalne, dwujęzyczne tablice informacyjne, których powstało w miastach rosyjskich bardzo wiele w związku z organizacją mundialu w roku 2018. Można również skorzystać z dubletów (transfer/translacja). 
Po drobiazgowej analizie wszystkich onimów z tekstu i doborze odpowiedników uzasadnionych w świetle projektu tłumaczeniowego (zrealizowanego lub nie) przychodzi czas na etap 3, podsumowujący.

Ad 3. Studenci wykonują tłumaczenie (może to być zupełnie nowy tekst, inny niż ten, nad którym pracowali poprzednio), do którego załączają komentarz o charakterze pragmatycznym, opisujący adresatów tłumaczenia, co już w znacznym stopniu uzasadnia wybory tłumacza odnośnie do onimów, a w pewnych przypadkach, jeśli jest taka potrzeba, dodają również komentarze dotyczące konkretnych rozstrzygnięć. Ma to szczególną wagę w sytuacji wariantywności odpowiedników oraz braku ekwiwalencji uznanej. Sprzyja to także poszerzaniu wiedzy metatranslacyjnej, świadomemu podejmowaniu decyzji, uczy spojrzenia na przekład tekstu jako na całościowy projekt, a nie tylko zbiór łamigłówek do rozwiązania.

\section{Zamiast podsumowania}

1. Pożądane jest uporządkowanie terminologii onomastycznej, wprowadzenie na listę ICOS terminu urbanonim, a w przypadku badań translatorycznych - sięganie do listy polskiej i międzynarodowej, ze świadomością, że specyficzny materiał badany (zwłaszcza wielojęzyczny) przy podejściu interdyscyplinarnym narzuca swoje własne ustalenia terminologiczne.

2. Ze względu na onimy jako obiekt badania konieczne jest rozważenie nie tylko kontekstu translacji i materiałów np. z korpusów równoległych, lecz również działań paratranslatorskich, a „nieświadomi tłumacze" powinni być uwzględniani jako odbiorcy zaleceń dotyczących oddawania onimów obcych w tekstach polskich.

3. W kwestiach bardziej szczegółowych:

a) Za celowe uważam stworzenie - w konkretnych parach językowych - list stałych ekwiwalentów konwencjonalnych części statusowych (apelatywnych) urbanonimów, podobnych do terminów ogólnogeograficznych w publikacjach KSNG, specyficznych dla odrębnych języków i krajów. W przypadku języka polskiego, w kierunku tłumaczenia z języka obcego na polski, byłyby to przede wszystkim ekwiwalenty słownikowe, natomiast taką funkcję mogą również 
pełnić transfery (w tym transliteracje, transkrypcje), szczególnie w odniesieniu do nowych desygnatów (przykład art cafe $-\mathrm{z}$ zastosowaniem angielszczyzny). Transfery ponadto mogą dotyczyć części apelatywnych nazw z języków odległych typologicznie, będąc początkowo konwencjonalnym zapisem, $\mathrm{z}$ czasem stając się pożyczką językową (i w tym sensie ekwiwalentem słownikowym). Podobne listy ekwiwalentów konwencjonalnych, w formie broszur, opracowań leksykograficznych, a najlepiej aktualizowanych list dostępnych online (dla par językowych), były pożądane dla instytucjonimów, socjoideonimów, eklezjonimów itp. Może jest to wyraz myślenia życzeniowego, jednak takie działania sprzyjałyby współpracy językoznawców onomastów i translatoryków oraz przedstawicieli innych dyscyplin (np. artystycznych) z tłumaczami praktykami.

b) Zagadnienie transliteracji angielskiej w kontekście dydaktycznym: zakres jej stosowania wobec urbanonimów rosyjskich w tekstach tłumaczonych na język polski można w coraz większym stopniu uzasadnić funkcją lokalizującą onimu, spójnością z przestrzenią wizualną opisywanych miast, a także wymiarem pragmatycznym tekstu.

c) W kontekście zastosowania technologii multimedialnych, szczególnie w obszarach z definicji interaktywnych, o silnie zaznaczonej funkcji lokalizującej urbanonimu, można rozważyć rezygnację z zabiegów translatorskich innych niż transfer, kojarząc taką formę zapisu $\mathrm{z}$ autentycznym plikiem dźwiękowym, np. w aplikacji na smartfon - co pozwoli obcokrajowcowi, bez obawy o problemy artykulacyjne, $\mathrm{z}$ całą pewnością odnaleźć pożądany obiekt. Tak więc smartfon „i do Kijowa doprowadzi”.

\section{Literatura}

\section{Źródła przykładów}

Czeczott J., 2017, Petersburg. Miasto snu, Wołowiec.

Strony internetowe zawierające konkretne nazwy własne:

Interaktywna mapa metra w Sankt-Petersburgu, http://www.metro.spb.ru/uploads/ $\mathrm{img} / \mathrm{map} / \mathrm{metromap2020.jpg} \mathrm{(dostęp:} \mathrm{2.04.2021).}$ 
Teatr Maryjski - w haśle Teatr Opery i Baletu im. Siergieja Kirowa, Encyklopedia PWN online, https://encyklopedia.pwn.pl/haslo/Teatr-Opery-i-Baletu-im-Siergieja-Kirowa;3985895.html (dostęp: 5.04.2021).

Teatr Maryjski - w artykule prasowym, https://www.muratorplus.pl/inwestycje/ inwestycje-publiczne/teatr-maryjski-w-petersburgu-slynny-teatr-opery-i-baletu-w-nowej-siedzibie-aa-RLck-Q2cr-XVoj.html (dostęp: 5.04.2021).

Teatr Maryjski (dla budowli w Petersburgu w Rosji) - zob. Uchwała KSNG nr 7/2016 z dnia 19 października 2016 r. (dostęp: 5.04.2021).

Улица Рубинштейна - w tekście prasowym, https:/www.vedomosti.ru/economics/ articles/2019/12/04/817884-sankt-peterburg-1999-2019 (dostęp: 5.04.2021).

Rubinstein, Rubinsztejn, https://www.rmfclassic.pl/encyklopedia/rubinstein-anton-g.html (dostęp: 5.04.2021).

Rubinsztajn - artykuł Daniela Grinberga w „Białostockich Tekach Historycznych”, https://repozytorium.uwb.edu.pl/jspui/bitstream/11320/2173/1/BTH_5_2007_ Grinberg.pdf (dostęp: 5.04.2021).

Дизайн-завод «Флакон» - tekst prasowy, https://www.kommersant.ru/doc/3931660 (dostęp: 5.04.2021).

Антикафе Local Time («Локал Тайм»), http://antikafe.com/antikafe/antikafe-localtime (dostęp: 5.04.2021).

Антикафе \& Коворкинг Хорошая Республика, http://www.goodrepublic.ru/ (dostęp: 5.04.2021).

Арт-кафе «Рукав», http://art-rukav.ru/cafe oraz https://www.instagram.com/ caferukav/ (dostęp: 5.04.2021).

Клуб Газгольдер, http:/gazgolder.com/ (dostęp: 5.04.2021).

Strona internetowa merostwa Moskwy, https://www.mos.ru/city/projects/design/ (dostęp: 1.03.2021).

\section{Wybrane publikacje KSNG}

Zmiany wprowadzone na XXXI posiedzeniu Komisji (21 marca 2007 roku), http:// ksng.gugik.gov.pl/nazew_pol_zm_2007-03-21.php.

Uchwała KSNG nr 7/2016 z dnia 19 października 2016 r. dotycząca zmian w polskich nazwach budowli świata, http://ksng.gugik.gov.pl/pliki/protokol_ksng/ uchwala_2016-7.pdf.

Zmiany egzonimów przyjęte na 111 posiedzeniu Komisji w dniu 2 grudnia 2020 roku, http://ksng.gugik.gov.pl/pliki/zmiany_egzonimow/zmiany_egzonimow_ na_111_posiedzeniu.pdf. 


\section{Literatura przedmiotu}

Bijak U., 2017, Transonimizacja, czyli „wędrówki nazw”, „Folia onomastica Croatica”, 26, s. $1-14$.

Bozhko Ye.M., Il'ner A.O., Korneyeva L.I., 2018, Kompromissnyy podkhod k peredache urbanonimov (na primere Yekaterinburga), ,Voprosy onomastiki”, t. 15, № 2, s. 223-238 [Божко Е.М., Ильнер А.О., Корнеева Л.И., 2018, Компромиссный подход к передаче урбанонимов (на примере Екатеринбурга), «Вопросы ономастики», т. 15, № 2, с. 223-238].

Cieślikowa A., 2011, Jakie korzyści daje onomastyce chrematonimia?, [w:] Chrematonimia jako fenomen współczesności, M. Biolik, J. Duma (red.), Olsztyn, s. 113-123.

Data K., 2016, Kulturowe uwarunkowania nazw ulic - tradycja i zmiana, „Acta Universitatis Wratislaviensis. Język a Kultura”, t. 26, s. 81-93.

Dunaj B., Mycawka M., 2012, Kilka uwag o klasyfikacjach nazw własnych, [w:] W komunikacyjnej przestrzeni naw własnych i pospolitych: księga jubileuszowa dedykowana profesorowi Robertowi Mrózkowi, I. Łuc, M. Pogłódek (red.), Katowice, s. 165-175.

Duplenskiy N., 2015, Pis'mennyy perevod. Rekomendatsii perevodchiku, zakazchiku i redaktoru, 3-ya redaktsiya, Moskva [Дупленский Н., 2015, Письменный перевод. Рекомендации переводчику, заказчику и редактору, 3-я редакция, M.], http://www.russian-translators.ru/perevodchesky-opit/practika/01/ (dostęp 1.03.2021).

Fernandes L., 2006, Translation of Names in Children's Fantasy Literature: Bringing the Young Reader into Play, „New Voices in Translation Studies”, 2, s. 44-57.

Gałkowski A., 2011, Chrematonomastyka jako autonomizująca się subdyscyplina nauk onomastycznych, [w:] Chrematonimia jako fenomen współczesności, M. Biolik, J. Duma (red.), Olsztyn, s. 181-193, (online): https://www.academia. edu/6258869/Artur_Ga\%C5\%82kowski_Chrematonomastyka_jako_autonomizuj\%C4\%85ca_si\%C4\%99_subdyscyplina_nauk (dostęp: 2.04.2021).

Gałkowski A., 2012a, Propozycje a rozstrzygnięcia terminologiczno-pojęciowe dotyczące chrematonimii, [w:] W komunikacyjnej przestrzeni naw własnych i pospolitych: księga jubileuszowa dedykowana profesorowi Robertowi Mrózkowi, I. Łuc, M. Pogłódek (red.), Katowice, s. 187-200.

Gałkowski A., 2012b, Terminologia onomastyczna. Aktualizowana lista podstawowych haseł terminologii onomastycznej w języku polskim, https://onomastyka. uni.lodz.pl/strona-glowna/terminologia-polska (dostęp: 2.04.2021).

Gałkowski A., 2018a, Definicja i zakres chrematonimii, „Folia Onomastica Croatica”, 27 , s. $1-14$. 
Gałkowski A., 2018b, Onomastyka translatoryczna a translatoryka onomastyczna, [w:] Onomastyka - neohumanistyka - nauki społeczne, U. Bijak, H. Górny, M. Magda-Czekaj (red.), Kraków, s. 129-138.

Hejwowski K., 2004, Kognitywno-komunikacyjna teoria przekładu, Warszawa. Hejwowski K., 2015, Iluzja przekładu, Katowice.

Kartushina Ye.A., 2017, Mnogoyazychiye v yazykovom landshafte gorodskoy sredy (na primere goroda Khel'sinki), „Vestnik Vyatskogo gosudarstvennogo universiteta”, s. 71-75 [Картушина Е.А., 2017, Многоязычие в языковом ландшафте городской среды (на примере города Хельсинки), „Вестник Вятского государственного университета", с. 71-75], https://cyberleninka. $\mathrm{ru} /$ article/n/mnogoyazychie-v-yazykovom-landshafte-gorodskoy-sredy-na-primere-goroda-helsinki (dostęp: 20.03.2021).

Kozłowska Z., Szczęsny A., 2018, Tłumaczenie pisemne na język polski. Kompendium, Warszawa.

Lewicki R., 2017, Zagadnienia lingwistyki przekładu, Lublin.

Lista ICOS kluczowych terminów onomastycznych, 2018, A. Gałkowski, U. Bijak (tłum. i oprac.), Grupa Terminologiczna ICOS International Council of Onomastic Sciences, Łódź-Kraków, http://onomastyka.uni.lodz.pl/wp-content/ uploads/2019/03/Lista-ICOS-kluczowych-termin\%C3\%B3w-onomastycznych. pdf (dostęp: 2.04.2021).

Nikitina TG., 2019, Gorodskoye onomasticheskoye prostranstvo: dialog nominatora i interpretatora, „Kommunikativnyye issledovaniya”, t. 6, № 1, s. 137-151 [Никитина Т.Г., 2019, Городское ономастическое пространство: диалог номинатора и интерпретатора, „Коммуникативные исследования”, т. 6, № 1, c. 137-151].

Puzey G., 2016, Linguistic Landscapes, [w:] The Oxford Handbook of names and naming, C. Hough (red.), with assistance from D. Izdebska, Oxford University Press, s. 395-421.

Razumov R.V., Goryayev S.O., 2019, Urbanonimicheskaya terminologiya: sistemy i problemy, „Nauchnyy dialog”, № 9, s. 130-145 [Разумов Р.В., Горяев С.О., 2019, Урбанонимическая терминология: системы и проблемы, „Научный диалог”, № 9, с. 130-145].

Remchukova Ye.N., Sokolova T.P., 2019, «Svoye» i «chuzhoye» v kommunikativnom prostranstve rossiyskogo goroda, „Kommunikativnyye issledovaniya”, t. 6, № 1, s. 31-50 [Ремчукова Е.Н., Соколова Т.П., 2019, «Свое» и «чужое» в коммуникативном пространстве российского города, Коммуникативные исследования", т. 6, № 1, с. 31-50].

Sandnes B., 2016, Names and Language Contact, [w:] The Oxford Handbook of names and naming, C. Hough (red.), with assistance from D. Izdebska, Oxford University Press, s. 540-553. 
Shmelëva T.V., 2019, Polikodovost' gorodskogo onomastikona, „Kommunikativnyye issledovaniya”, t. 6, № 1, s. 51-66 [Шмелёва Т.В., 2019, Поликодовость городского ономастикона, „Коммуникативные исследования”, т. 6, № 1, c. 51-66].

Suprun V.I., 2011, Razmyshleniya nad onomasticheskoy terminologiyey, „Izvestiya VGPU”, № 8, s. 133-138 [Супрун В.И., 2011, Размышления над ономастической терминологией, „Известия ВГПУ”, № 8, с. 133-138].

Szczęsny A., 2011, Embarras de choix - nazwy własne jako odwieczny problem w dydaktyce tłumaczenia pisemnego. Między normą a uzusem (na przykładzie tekstów polskich i rosyjskich), „,Rocznik Przekładoznawczy. Studia nad Teorią, Praktyką i Dydaktyką Przekładu”, 6, s. 193-210.

Szczęsny A., 2017, Tradycja, tłumaczenie czy transkrypcja? O mikrotoponimach i antroponimach z perspektywy dydaktyki tłumaczenia, „Komunikacja Specjalistyczna”, 13, s. 61-78.

Szczęsny A., 2019, Trudnosti peredachi imën sobstvennykh. Mikrotoponimy v kinoperevode s tochki zreniya didaktiki [Трудности передачи имён собственных. Микротопонимы в кинопереводе с точки зрения дидактики], [w:] Język rosyjski jako obcy. Dydaktyka przekładu, słowniki i pomoce naukowe, D. Muszyńska-Wolny, P. Michałowski, D. Urbanek (red.), Warszawa, s. 83-98.

Świtała-Cheda M., 2015, Nazwy wybranych form ochrony przyrody - podobieństwa i różnice, [w:] Mikrotoponimy i makrotoponimy w komunikacji i literaturze, A. Gałkowski, R. Gliwa (red.), Łódź, s. 183-192.

Włoskowicz W., 2021, Uzus toponimiczny. Zarys teorii na przykładzie polskiej toponimii Huculszczyzny, Kraków.

Yermolovich D.I., 2001, Imena sobstvennyye na styke yazykov i kul'tur, Moskva [Ермолович Д.И., 2001, Имена собственные на стыке языков и культур, М.]. Yermolovich D.I., 2005, Imena sobstvennyye: teoriya i praktika mezh"yazykovoy peredachi, Moskva [Ермолович Д.И., 2005, Имена собственные: теория и практика межъязыковой передачи, M.].

Zagidullina M.V., Krayeva S.S., 2019, Perevod antroponimov v mediadiskurse: didakticheskiy aspekt, „Vestnik Chelyabinskogogosudarstvennogo universiteta”, № 10(432), Filologicheskiye nauki, Vyp. 118, s. 64-72 [Загидуллина М.В., Краева С.С., 2019, Перевод антропонимов в медиадискурсе: дидактический аспект, „Вестник Челябинского государственного университета”, № 10(432), Филологические науки, Вып. 118, с. 64-72]. 


\section{Urbanonyms as a translational difficulty - from the perspective of translation didactics}

\section{Summary}

This article is devoted to proper names denoting objects of urban space, which are variously classified by specialists in onomastics (especially chrematonomastics) as well as translation onomastics. The first part of the article presents selected approaches to the description of the urban onomasticon and different divisions, which - in the author's opinion - can be used at different stages of the translation process.

The second part contains the reflections of specialists in Translation Studies concerning proper names, including the names of urban objects. In the discussion of selected concepts, the text functions of this group of onyms are noted. Attention is also drawn to various methods and techniques of their transmission in the translated text.

The third part of the article brings readers closer to the project of a research group of linguists from Yekaterinburg, whose goal was to systematise the principles of transmitting the names of urban objects in English. Discussing this project, the author notes quite new phenomena and trends in the actual translation and paratranslation activities. Along with them, possible and popular solutions as well as the expansion of the scope of application of certain techniques (primarily English transliteration) in the media discourse and in the information space are outlined.

The last part of the article presents didactic suggestions: the author provides specific examples of urban onomasticon-related translation difficulties, which were discussed during classes in translation from Russian into Polish. At the same time, the author offers a certain sequence of exercises that are an introduction to the problems with proper names in translation.

Keywords: proper names, chrematonyms, microtoponyms, urbanonyms, text functions, translation onomastics, paratranslation activity, transfer, transliteration, translation, recommendations to translators

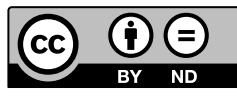




\section{Aneks}

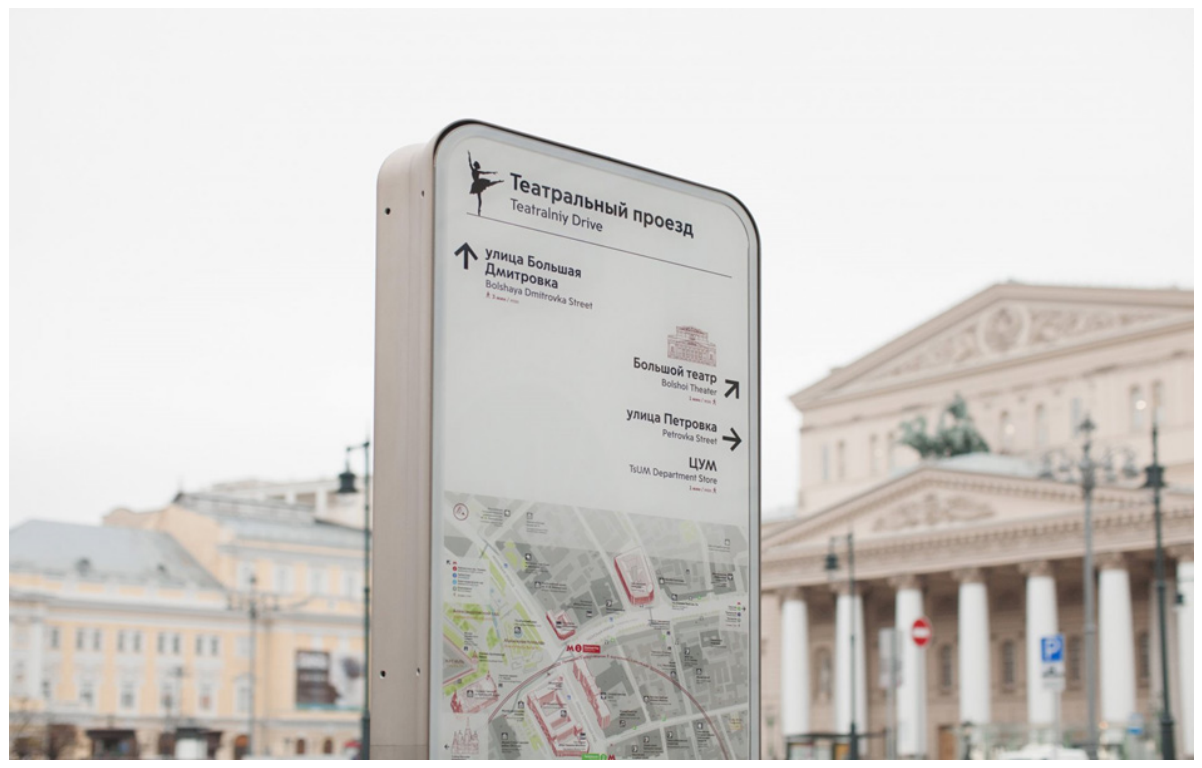

Fotografia pochodzi ze strony internetowej merostwa Moskwy 